\title{
Linking life-history traits, spatial distribution and abundance of two species of lugworms to bait collection: A case study for sustainable management plan
}

\author{
De Cubber Lola ${ }^{1}$, Lefebvre Sébastien ${ }^{1,2}$, Fisseau Charline ${ }^{3}$, Cornille Vincent ${ }^{1}$, \\ Gaudron Sylvie Marylène ${ }^{1,4,5,{ }^{\star}}$
}

\author{
${ }^{1}$ Univ Lille, Univ Littoral Cote dOpale, UMR Lab Oceanol \& Geosci 8187, CNRS, F-62930 Wimereux, \\ France. \\ 2 IFREMER, HMMM Lab Ressources Halieut, F-62200 Boulogne Sur Mer, France. \\ ${ }^{3}$ Agence Aires Marines Protegees, Parc Nat Marin Estuaires Picards \& Mer Opale, F-62200 Boulogne \\ Sur Mer, France. \\ ${ }^{4}$ Sorbonne Univ, UFR 918, F-75005 Paris, France. \\ ${ }^{5}$ Sorbonne Univ, UFR 927, F-75005 Paris, France.
}

*Corresponding author : Sylvie Marylène Gaudron, email address : sylvie.gaudron@upmc.fr

\begin{abstract}
:
Arenicola spp. are marine benthic polychaetes dug for bait by anglers. Without regulation, this activity can lead to the decrease of lugworms' population meanwhile affecting the physical characteristics of the beach and the biodiversity. Here, we identified through morphology and genetics two species of lugworms, Arenicola marina and $A$. defodiens, within a Marine Protected Area of the Eastern English Channel (France). For each species, abundance and spatial distribution were assessed using a stratified random sampling and interpolation at four studied sites, as well as some life-history traits. These data were compared to lugworms' collection data to estimate its sustainability and to provide potential management measures. At one site, A. marina was present in large numbers on the higher and middle shore, whereas $A$. defodiens occupied the lower shore. At the other sites, both species cooccurred on the lower shore, and $A$. marina individuals were less numerous and lacking recruits. Spawning periods for $A$. marina occurred in early autumn and in late autumn for $A$. defodiens. The size at first maturity of $A$. marina was at $3.8 \mathrm{~cm}$ of trunk length (between 1.5 and 2.5 years old). One site (Au) appeared in need for management when linking abundance data with bait collection, where harvest of both species represented $\sim 14 \%$ of the total amount of lugworms and was above the carrying capacity of the beach for $A$. marina. The retail value associated to lugworm harvesting within the MPA was estimated at the same level as the shrimp retail value. Our results highlight the need for some fishery regulations.
\end{abstract}




\section{Highlights}

- At Wimereux Arenicola defodiens and A. marina live separately (typical spatial distribution pattern). - At Le Touquet and Fort Mahon Arenicola defodiens and A. marina live in sympatry. The size at first maturity of Arenicola marina is $3.8 \mathrm{~cm}$ of trunk length (between 1.5 and 2.5 years old). At Ault, the harvest of Arenicola marina was above the carrying capacity of the beach. The retail value associated to lugworm harvesting within the MPA was $232447 €$.

Keywords : Arenicola marina, Arenicola defodiens, Spawning, Population structure, Size at first maturity, Recreational fisheries, Conservation, English channel 
Arenicola spp. (Annelida Polychaeta), are marine benthic coastal ecosystem engineers living in burrows on intertidal and subtidal soft-sediment beaches and estuaries from the Arctic to the Mediterranean (Volkenborn, 2005). Two cryptic species of the genus Arenicola were recorded in the North Sea and the English Channel: A. marina (Linnaeus, 1758) and $A$. defodiens (Cadman and Nelson-Smith, 1993). They were formerly described as two varieties of the same species, A. marina being the "littoral" variety, and A. defodiens the "laminarian" variety (Luttikhuizen and Dekker, 2010). Indeed, A. marina rather occupies the higher shore to mid-shore in a U-shape gallery, between 10 to $40 \mathrm{~cm}$ below the sediment surface, while $A$. defodiens is present on the lower shore to subtidal area in a deeper (up to 1-meter deep) and Jshape gallery (Cadman and Nelson-Smith, 1993; Cadman, 1997). Only small morphological differences exist between the two species, the most notable being the annulations patterns of the first setigers and the shape of the gills (Cadman and Nelson-Smith, 1993). Thus, their species discrimination was proven by genetics (Cadman and Nelson-Smith, 1990) and reconfirmed recently using COI and 16S gene markers (Luttikhuizen and Dekker, 2010; Pires et al., 2015). Both species are dioecious and iteroparous (Watson et al., 1998) and their benthopelagic lifecycle (Farke and Berghuis, 1979a; Reise, 1985), has only been described for $A$. marina. For this species, after the spawning event in early autumn, and before the recruitment in spring, young stages experience two successive dispersal phases, with a temporary settlement in between, where at a 'post-larval' stage the worm lives in a mucus tube attached to various substrates (sheltered soft-sediment, macroalgae or mussel beds) (Farke and Berghuis, 1979a,b; Reise, 1985; Reise et al., 2001). Arenicola spp. play a key role in bioturbation of soft sediments (Kristensen, 2001) and in local trophic networks (Reise, 1985; Clarke et al., 2017). Moreover, despite lugworms are not considered yet as a fisheries species (as not directly consumed), they represent a high commercial marine value showing an important biomass extraction according to Watson et al. (2017a), who estimated a global landing for polychaete bait (including lugworms) up to 120000 tonnes, representing $£ 5.9$ billion in 2016. Lugworm collection by professional or recreational fishermen may impact the size and age structure of a population, such as its abundance and distribution (Blake, 1979; McLusky et al., 1983; Olive, 1993) with possible population crashes caused by overexploitation (Olive, 1993). In addition, bait diggers can affect the physical characteristics of the beach perturbing the other associated fauna (invertebrates, wading birds, etc.) (Beukema, 1995; Clarke et al., 2017; Watson et al., 2017b). 
In consequence, several authors call for a management (Watson et al., 2017a), and

100 particularly, a sustainable management of these species (Clarke et al., 2017).

101 Fisheries management can be defined as "the integrated process of information gathering, analysis, planning, consultation, decision-making, allocation of resources and formulation and

103 implementation, with enforcement as necessary, of regulations or rules which govern fisheries activities in order to ensure the continued productivity of the resources and the accomplishment of other fisheries objectives" (FAO, 2002a). In other words, this consists in maintaining its population at healthy levels, which is, in terms of population's dynamics, a population with sustainable birth, growth and survival rates (Beverton and Holt, 1957). The management can be implemented through education, or through enforced harvest regulations (Watson et al., 2015). The latter are in general applied either on the fishermen themselves, implementing licenses or fees, gear or fishing methods restrictions, closing times, season or area restrictions, either on the resource, limiting the length or quantity (bags) of the collected species mainly (FAO, 2012). Both controls are used to limit the overall mortality, or the mortality of specific individuals in the population, based on its features (FAO, 2012).

114 Several kinds of regulations for bait collection have already been enforced around the world, either for recreational or professional fishermen: licensing has been implemented in the

116 United States and the United Kingdom (Watson et al., 2015), quotas have been implemented 117 in Portugal (Xenarios et al., 2018) and some areas have been closed in the UK (Olive, 1993; 118 Rogers, 1997). For Arenicola spp. the last two options have already been implemented in 119 some European places: a limitation to 100 individuals in a defined area in the North of France 120 (Direction interrégionale de la mer Manche Est-mer du Nord, 2015) or the closure of areas 121 where the lugworm population crashed in the UK (Olive, 1993; Rogers, 1997). Although 122 protecting lugworms, the main purpose of these management methods is sometimes rather to 123 protect the habitat features or the wading birds disturbed by fishermen (Watson et al., 2017b).

124 Besides, these management measures are merely restrictions, often taken without any 125 considerations of the life history traits of the local populations (Watson et al., 2017a). Studies 126 linking bait collection data to abundance, spatial distribution and life history traits of lugworm 127 are scarce. Xenarios et al. (2018) assessed the sustainable levels of some polychaetes species

128 (Diopatra neapolitana), only taking into account the harvest effort, and Blake (1979)

129 combined the harvest effort to population data (e.g. density and size structure). Nevertheless, 130 the only study of this kind dealing with lugworms (Blake, 1979) was performed before the 
131 knowledge of the co-occurrence of two potential species of the genus Arenicola inhabiting the intertidal area (Cadman, 1997).

133 In this study, we have assessed the abundance and the spatial distribution of several local 134 populations of Arenicola spp. within a newly created MPA from temperate coastal areas 135 located in the Eastern English Channel, as well as some life-history traits such as spawning 136 period, size at first maturity, population structure and recruitment period. Additional data on 137 lugworms' collection by recreational bait diggers within the MPA was included in order to estimate the potential sustainability of the different lugworms' population and to provide relevant potential management measures when needed.

\section{Material and Methods}

\subsection{Study Area}

142 The study area is located in the Eastern English Channel and is part of a marine protected area 143 (MPA): the Parc naturel marin des estuaires picards et de la mer d'Opale created in 2012 (Fig.

144 1). The coastline is mainly composed of hydrodynamically exposed sandy beaches of fine to medium sands ( 0.05 to $0.5 \mathrm{~mm}$ grain size), as well as some rocky shores, and includes three major estuaries of muddy sands ( 2 to $3 \%$ silt): the Somme, the Authie and the Canche estuaries (Rolet et al., 2014, 2015). The tidal regime is semi-diurnal and macrotidal and, amplitude may exceed $8 \mathrm{~m}$, with the largest amplitudes occurring around 2 days before the full moon (Migné et al., 2004; Rolet et al., 2015). Sampling sites (Fig. 1) were chosen at four locations along the shore of the MPA, where recreational fishermen had often been observed digging worms, in order to assess the need for management of this activity: 1) Wimereux (Wx) $\left(50^{\circ} 46^{\prime} 14^{\prime \prime} \mathrm{N}\right.$ and $1^{\circ} 36^{\prime} 38^{\prime \prime}$ E), 2) Le Touquet (LT) (50॰31'07" N and 1'35'42" E), 3) Fort Mahon (FM) (50²0'31" N and 1 $\left.{ }^{\circ} 34^{\prime} 11^{\prime \prime} \mathrm{E}\right)$ and, 4) Ault (Au) $\left(50^{\circ} 06^{\prime} 07^{\prime \prime} \mathrm{N}\right.$ and $1^{\circ} 26^{\prime} 58^{\prime \prime}$

154 E). LT and FM are composed of large exposed sandy beaches, when Wx and Au are a mixture 155 of sandy beaches and rocky shores mainly colonized by algae and mussels on the intertidal 156 and subtidal areas.

\subsubsection{Sampling strategy}

159 Spatial distributions of lugworms were investigated on the sandy shore in April-Mai 2016 at 160 the four sites (Wx, LT, FM and Au) during spring tide periods. Formerly, lugworms 161 distributions were assessed by samplings on uniformly distributed points along transects 162 (Beukema and De Vlas, 1979; Beukema, 1995). However, on the studied sites, distributions 
of lugworms were highly aggregative (with spots of faecal casts and spaces without faecal casts next to them). Therefore, a stratified random sampling approach was chosen (Fagan and Nelson, 2017), in order to improve the performance of the spatial interpolation methods (Li and Heap, 2008). At each site, the area was subdivided into a grid of equally-sized rectangle boxes: a grid of $100 \mathrm{~m}$ x $50 \mathrm{~m}$ divided into 18 boxes at $\mathrm{Wx}$ and at $\mathrm{Au}$, and, a grid of $100 \mathrm{~m} \mathrm{x}$ $70 \mathrm{~m}$ divided into 24 boxes at LT and at FM (Fig. 1). In each box, a random sampling point was computed (Fig.1), where the abundance of lugworms (both species combined) was assessed by counting the number of faecal casts in three quadrates placed randomly, of 0.0625 $\mathrm{m}^{2}$ (when densities were higher than 10 faecal casts), or of $1 \mathrm{~m}^{2}$ (when densities were lower than 10 faecal casts). Every 3 to 5 sampling points, lugworms were dug using either an Alvey bait pump (Decathlon ltd, extracting the worm by suction), a fork or a shovel, and the proportion of each species was calculated at the different bathymetries to correct the number of individuals belonging to each species.

\subsubsection{Species identification}

Species identification was determined morphologically by the observation of the annulations pattern on the second chaetigerous segment (two annulations for Arenicola defodiens and three for A. marina) (Cadman and Nelson-Smith, 1993). Subsamples of tissue of each worm were kept in a solution of absolute ethanol at $-20^{\circ} \mathrm{C}$. The DNA of 3 random individuals of $A$. marina and 3 random individuals of $A$. defodiens was then extracted using the NucleoSpin ${ }^{\circledR}$ Soil kit according to manufacturer's instruction (Macherey-Nagel), amplified and sequenced by Genoscreen ltd (Institute Pasteur de Lille, France) in order to confirm the presence of the two different species within the MPA. Fragments of the mitochondrial cytochrome oxidase I-encoding gene (COImt DNA) $(\sim 670 \mathrm{pb})$ were amplified using the universal primers: LCO 1490 (5'-GGTCAACAAATCATA AAG ATA TTG G-3') and HCO 2198 (5'-TAAACT TCA GGG TGA CCA AAA AAT CA-3’) (Folmer et al.,1999).

Polymerase Chain Reaction (PCR) was performed according to Pires et al. (2015): an initial denaturing step of $3 \mathrm{~min}$ at $94^{\circ} \mathrm{C}$, followed by 34 cycles at $94^{\circ} \mathrm{C}$ for $1 \mathrm{~min}, 45^{\circ} \mathrm{C}$ for $30 \mathrm{~s}$ for hybridization, then $2 \mathrm{~min}$ at $72^{\circ} \mathrm{C}$, and a final extension for $5 \mathrm{~min}$ at $72^{\circ} \mathrm{C}$. COI sequences were manually checked using bioedit Ver. 7.0.0. (Hall, 1999). Each COI sequence was then deposited in GenBanK (Supplementary Material: Table A) and aligned with other COI sequences of $A$. marina and $A$. defodiens (retrieved from GenBank), as described by Pires et al. (2015). This multiple alignment of COI sequences was exported to the software MEGA v7 
195 (Kumar et al., 2016) using ClustalW, in order to construct a molecular phylogenetic tree analysis based on the maximum likelihood method (Supplementary Material: Fig. B).

\subsubsection{Data analyses}

198

199

200

201

202

203

204

205

206

To assess the spatial distribution and abundance of Arenicola spp., first, the total number of lugworms at each point was estimated by the number of faecal casts (Farke et al., 1979), assuming that one worm produced 0.84 cast.tide $^{-1}$ in A. marina (Supplementary Material: Fig. C). We assumed that both species produce approximately the same amount of casts per tide. The relative proportions of $A$. marina and $A$. defodiens were recorded for each collection point taking into account the bathymetry (height above chart datum). Since only few individuals could be collected in spring 2016, the data from autumn and winter 2015 was also used (Table 1). Bathymetries were obtained from the interregional project "CLAREC, INSU CNRS M2C-UNICAEN" (http://www.unicaen.fr/dataclarec/home/elevations.html). When no bathymetry record was available (FM), we used the distance from the shoreline as a proxy. The shoreline HISTOLITT ${ }^{\circledR}$ was taken from the SHOM, the hydrographic and oceanographic service of the French navy (http://diffusion.shom.fr/loisirs/trait-de-cote-histolittr.html). The existence of a correlation between the proportions of the two species and the bathymetry or the shoreline distance was investigated (Spearman correlation test) at each site separately. When a correlation between the proportion of A. marina and A. defodiens and bathymetry could be established (Wx), a fitting model was adjusted on Matlab R2015b using the Curve Fitting Toolbox and a sigmoid model inspired by Cadman (1997) (Supplementary Material: Fig. D). The number of individuals of each species was then calculated following the fitted model at each collection point's bathymetry. When no particular correlation was noticed (LT, FM) (Supplementary Material: Fig. E), the number of individuals of each species was calculated from the overall proportion of the individuals of both species from autumn 2015 to spring 2016. Eventually, when the number of individuals of $A$. marina and A. defodiens was assessed in every point of the grid, it was then interpolated on QGis 2.18.0 (QGIS development team, 2016) using the inverse distance weight (IDW) method. Interpolations were superimposed to EUNIS habitat communities maps obtained from Rolet et al. (2014) and from additional samplings performed according to Rolet et al. (2014) at FM and Au in Spring 2016, which is based on species identification of the macrofauna and on the particle size analysis (Supplementary Material: Table F). The number of individuals of each species was obtained on the whole grid from the interpolation and then reduced to $1 \mathrm{~m}^{2}$ to get the 
mean density. The significance of the difference of densities between sites was then estimated with a chi-squared test for each species separately, performed on R (R Core Team, 2017).

1.3. Life-history traits of the lugworm populations

\subsubsection{Sampling strategy}

Spawning dates of both species were investigated for two successive breeding seasons, from September 2015 to January 2016 and from September 2016 to January 2017, at the four studied sites. Individuals were dug with a bait pump monthly on the lower shore or with a fork on the mid-shore, at low tide (Table 1). The population structure of Arenicola marina was investigated only at Wx (Fig. 1) within the intertidal area at three locations from the low/middle shore to the higher shore ( $0 \mathrm{~m}$ of bathymetry: $50^{\circ} 46^{\prime} 0.1^{\prime \prime} \mathrm{N}$ and $1^{\circ} 36^{\prime} 20.3^{\prime \prime} \mathrm{E}, 0.9$ $\mathrm{m}$ of bathymetry (above $0 \mathrm{~m}$ ): 5046'1.7' $\mathrm{N}$ and 1'36'14.4” E and, $2.3 \mathrm{~m}$ of bathymetry (above $0 \mathrm{~m}$ ): $50^{\circ} 46^{\prime} 2.5^{\prime \prime} \mathrm{N}$ and $1^{\circ} 36^{\prime} 10.6^{\prime \prime} \mathrm{E}$ ) in July 2017. During low tide, 30 individuals from each location were collected by digging the sediment (between 5 and $30 \mathrm{~cm}$ beneath the surface $)$, either with a pump, or a fork or by sieving $(0.5 \mathrm{~mm}$ mesh) the sediment on the higher shore for the smaller individuals. This sampling strategy was repeated in September 2017 to assess the size at first maturity of $A$. marina at Wx.

\subsubsection{Laboratory measurements}

After each sampling, all worms were put in separated containers filled with seawater. Worms were maintained in the laboratory during $24 \mathrm{~h}$ to $48 \mathrm{~h}$ at $15^{\circ} \mathrm{C}$ in a cold room to allow gut contents to devoid prior to observations (Watson et al., 2000). After identification, worms were anesthetized in three successive solutions of twice-filtered sea water (TFSW, $0.45 \mu \mathrm{m}$ and $0.2 \mu \mathrm{m}$ ) at $1 \%, 2.5 \%$ and $5 \%$ of ethanol (Gaudron and Bentley, 2002). Each individual was measured (total length and trunk length) and weighted (wet weight). To assess their reproductive status, biopsies of the coelomic fluid were performed on individuals of Arenicola marina and $A$. defodiens (Table 1) with a sterile hypodermic syringe. The gametes were then rinsed twice in TFSW and kept in ethanol $(96 \%)$ at $4{ }^{\circ} \mathrm{C}$. Fifty random oocytes of each female were measured under the microscope assisted by the software Motic Image Plus 2.0. Reproductive structures of males (rosettes, morulae and spermatozoids) were analyzed using the same method. To assess the size at first maturity, the occurrence of gametes was searched in coelomic fluids of 106 individuals of A. marina.

\subsubsection{Data Analysis}


259 Spawning periods of both species were inferred by using both the oocyte diameter frequency distributions (Watson et al., 1998) and the presence of male gamete structures such as spermatozoids or morulae, only present in mature individuals (Dillon and Howie, 1997).

262 Furthermore, observation of spontaneous spawning events in the laboratory was considered as additional evidence that lugworms were at a maturity stage and ready to release gametes. The estimated spawning periods were then compared with environmental local data such as tidal coefficients and water temperature (data provided by "Service d'Observation en Milieu Littoral, INSU-CNRS, Wimereux", bottom coastal point: http://somlit.epoc.ubordeaux1.fr/fr/).

Population and age structures of Arenicola marina

In Arenicola spp., no permanent structures with year marks have been found (Beukema and De Vlas, 1979) and the population structure can only be approached through the analysis of the different size of cohorts, since spawning and recruitment only happen once a year and each cohort belongs therefore to a separate year. Only the population and age structures of $A$. marina at Wx were assessed through the analysis of size frequencies on the trunk length (TL) frequency distributions of 5-mm size class intervals, using a Bhattacharya analysis $(\mathrm{N}=194)$ performed on the specific routine in FISAT II package (FAO, 2002b) according to Romano et al. (2013). To assess the goodness of the modal separation, separation indices (SI) were computed with values of SI $>2$ being considered as successfully separated. Mean TLs, standard deviations and separation indices were calculated for each of the identified cohorts. Significant differences in TL of A. marina were assessed using a one-way analysis of variance (ANOVA) and a post-hoc Tukey test on R (R Core Team, 2017) (RStudio Team, 2016). Normality of residuals was assessed by the Shapiro test $(\mathrm{p}>0.05)$, and homoscedasticity was tested by the Bartlett test ( $\mathrm{p}>0.05)$ on R (R Core Team, 2017).

First size and age at maturity of Arenicola marina

284 The first size at maturity is the size at which more than $50 \%$ of the individuals are 'mature'

285 (i.e. able to produce gametes, thus adult stage). Since reproductive organs are difficult to 286 observe in Arenicola spp. (Cassier et al., 1997), the presence/absence of gametes in the 287 coelomic fluid was checked at the end of the gametogenesis period (September). These observations allowed to estimate the number of individuals containing gametes (adults), and that without gametes (juveniles). The cumulated frequency of the proportion of 'mature' individuals per trunk length (TL) class was then calculated and the size at first maturity was 
considered the size at which the cumulated frequency equaled to 0.5 (or $50 \%$ ). The differences in TL between adult males and females of $A$. marina at $\mathrm{Wx}$, and between adults and juveniles (at the same site) were assessed using a non-parametric Kruskal-Wallis (K-W) test as distributions were not normal (Shapiro test, $\mathrm{p}<0.05$, performed on $\mathrm{R}$ ( $\mathrm{R}$ Core Team, 2017)).

\subsection{Survey of bait collection within the MPA}

On the whole MPA's foreshore, the number of recreational fishermen digging lugworms was assessed through on-site monitoring between one hour before and after the low tide at least once a month. Given the high variability of the number of fishermen, four sites were chosen (Wx, LT, FM and Au) that represented the different intensities of digging effort met within the MPA. The number of worms collected per fisherman was assessed as in Xenarios et al. (2018), through field surveys, between 2014 and 2016. Given the high variability of the presence of diggers along the year (Xenarios et al., 2018), categories (in terms of numbers of fishermen) were established according to the weather conditions (temperature, pluviometry, photoperiod, maximum wind strength and atmospheric pressure), the tidal conditions (tidal coefficient, tidal range and low tide time), and the availability of fishermen (French and Belgium holidays, working days, week-ends, period of the year, morning or afternoon). The mean number of diggers per category and per site and the associated standard deviation were calculated, as well as the number of occurrences of each category in one year, which gave the number of diggers per site for this category in one year, as well as for the whole MPA. The total number of diggers for each site and for the whole MPA was then calculated summing the results of each category. The lugworms' extraction levels were calculated multiplying the total number of fishing sessions per site by the mean number of worms dug out by one fisherman in one fishing session. Finally, the retail value for the whole MPA and for each of the four studied sites was assessed from the numbers of dug lugworms and from the local retail prices taken from websites and from local retailers as in Watson et al. (2017a).

\subsection{Linking abundance and spatial distribution to extraction levels of lugworms}

At the four studied sites, the mean number of lugworms available for bait diggers was assessed from the mean densities of lugworms established in this study, the surface of the foreshore and the percentage of lugworms weighing more than $3 \mathrm{~g}$ (weight considered by Olive (1993) as the limit at which worms get valuable). Then, these data were compared to the estimated number of dug lugworms assessed by the survey. 


\section{Results}

2.1. Species identification, spatial distribution and abundance

The 6 random individuals chosen for a molecular analysis based on the COI genes confirmed the morphological identification (barcoding) (Supplementary Material: Fig. B, Table A). A 14-15\% of nucleotide divergence was found between the COI genes of Arenicola marina and $A$. defodiens. At Wx, a significant correlation was found between the proportion of each species and bathymetry (Spearman, $\rho=0.9, \mathrm{p}<0.001$ ) and a relation could be established (Supplementary Material: Fig. D). It appeared that A. marina was present above $-1 \mathrm{~m}$ of bathymetry and $A$. defodiens below -2 m of bathymetry, with a small transition in between, where the two species could live in sympatry. On the other studied sites, no correlation was found between the proportion of each species and bathymetry or distance from the shoreline (LT: Spearman, $\rho=-0.09, p>0.1$; FM: Spearman, $\rho=0.25, p>0.1$ ) (Supplementary Material: Fig. E). At Wx, A. defodiens was found on the lower shore, on the A2.23 EUNIS habitat and A. marina was mainly present on the higher shore, on the A2.223 EUNIS habitat (Fig. 2; Supplementary Material: Table F). At LT and FM, both species appeared to live in sympatry. Lugworms at LT were present on the A2.23 EUNIS habitat and at FM, lugworms were found on the A5.231 EUNIS habitat (Fig. 2; Supplementary Material: Table F). At Au, A. defodiens was found on the lower shore, on the A2.23 EUNIS habitat (Fig. 2; Supplementary Material: Table F), but no conclusions were made regarding the distribution of $A$. marina on this site since only a single individual was collected. The mean densities of $A$. defodiens did not appear to vary significantly between sites (between $0.25 \pm 0.05$ and $0.70 \pm$ 0.05 individuals. $\mathrm{m}^{-2}$ at all sites $)\left(\mathrm{CHI}^{2}, \mathrm{p}=0.96\right)$ in comparison with $A$. marina $(6.5 \pm 0.8$ individuals. $\mathrm{m}^{-2}$ at $\mathrm{Wx}$, around 0.2 individuals. $\mathrm{m}^{-2}$ at LT and FM), where it varied significantly (CHI $\left.{ }^{2} ; \mathrm{p}<0.01\right)$ (Fig. 2).

349 For both species, the frequency distribution of the oocytes diameters evolved from a bimodal distribution for females carrying oocytes in oogenesis, with one peak of small oocytes $(<50$ $\mu \mathrm{m})$ and one peak of larger oocytes $(>100 \mu \mathrm{m})$, to a unimodal distribution with one single peak of large oocytes $(\sim 150 \mu \mathrm{m}$ for Arenicola defodiens and $\sim 180 \mu \mathrm{m}$ for A. marina) for

353 females where oocytes have completed vitellogenesis and are ready to be released (example at 354 Wx for A. defodiens on Fig. 3, see further details in Supplementary Material: Figs. G. 1-4). 
Spawning events of $A$. marina (Supplementary Material: Fig. H) were assumed to take place at the beginning of autumn in 2015 and 2016 when water temperatures are $\sim 12$ to $16^{\circ} \mathrm{C}$. We estimated that A. marina spawned between September (at Wx) and mid-November (at FM) in 2015, and, between September (at Wx) and October (at FM and LT) in 2016 (Supplementary Material: Figs. G.1 and G.2), possibly during spring tides. Spawning events of $A$. defodiens (Supplementary Material: Fig. H) were assumed to take place at the end of autumn and at the beginning of winter in both 2015 and 2016 for water temperatures between $\sim 7$ to $11^{\circ} \mathrm{C}$. We estimated that $A$. defodiens spawned between December (at Au, FM and LT) and January (at Wx) in 2015, and between November (at LT and FM) and December (at Wx) in 2016 (Supplementary Material: Figs. G.3 and G.4), possibly during spring tides. These periods of spawning were confirmed by the presence of spermatozoids within the coelomic fluid in males of both species (data not shown).

\subsubsection{Population structure and age}

At Wx, individuals of Arenicola marina ranged from 0.3 to $9 \mathrm{~cm}$ TL. The size-frequency distribution was multimodal ( 5 modes, SI $>2$ ) (Table 2, Fig. $4 \mathrm{a}$ ), suggesting the presence of 5 different age groups, the first one being the recruits' group $(0.90 \pm 0.37 \mathrm{~cm} \mathrm{TL})$. Since no recruits were spotted in April-May 2016 but some were observed in July 2017, recruitment may happen at the end of spring and/or beginning of summer at Wx. TL means of the three groups of TL delimited by the high ( $2.3 \mathrm{~m}$ of bathymetry), medium ( $0.9 \mathrm{~m}$ of bathymetry) and low ( $0 \mathrm{~m}$ of bathymetry) levels on the shores were significantly different (ANOVA: $\mathrm{F}_{(1,2)}=$ 67.16; $p<0.001$; Post-hoc Tukey $p<0.001$ ), which suggests that recruitment happens on the upper shore (Fig. 4b). Given the weight-size relationship found for A. marina at Wx (Fig. 4c), lugworms reached the weight of $3 \mathrm{~g}$ between 5 and $9 \mathrm{~cm}$, which means not before reaching 3 years old. At Wx, $12.6 \%$ of the sampled A. marina and $100 \%$ of the sampled A. defodiens had a weight superior to $3 \mathrm{~g} .100 \%$ of the individuals of the two species were above $3 \mathrm{~g}$ at the other sites, except for A. marina at Au, where the only individual collected weighted $2.5 \mathrm{~g}$.

\subsubsection{First size at maturity of A. marina}

Adult lugworms ranged from 2.5 to $6.3 \mathrm{~cm}$ (TL). The first size at maturity of Arenicola marina at Wx was assessed at $3.8 \mathrm{~cm}$ of TL (Fig. 5), which corresponds approximately to $1 \mathrm{~g}$ of wet weight (Fig. 4c). No significant difference was found between the lengths of males and females $(\mathrm{K}-\mathrm{W}: 0.63, \mathrm{p}>0.05)$, then all the data were analysed together. A highly significant difference between the size of juveniles $(2.29 \pm 0.97 \mathrm{~cm})$ and adults $(3.92 \pm 0.91 \mathrm{~cm})$ was 
observed (K-W: 0.96, p < 0.001) (Fig. 5). According to the population structure of A. marina from Wx, lugworms become adult between 1.5 and 2.5 years-old (Fig. 4a, Table 2).

\subsection{Bait collection data and retail value}

Most of the data presented here is available at https://estamp.afbiodiversite.fr/donnees. In total, 3638 on-site observations were made within the MPA between 2014 and 2016. Among them, 88 were performed at Wx, 54 at LT, 60 at FM and 61 at Au. At these sites, 27 fishermen's baskets were randomly selected in order to estimate the number of dug lugworms (10 at Wx, 5 at LT and 12 at FM). The number of recreational diggers was highly variable along the MPA's foreshore. Au was the site where more lugworms' diggers were spotted on the whole MPA, with less than 4000 diggers recorded in 2015. On the other studied sites, the number of recreational diggers ranged from $\sim 300$ at FM, $\sim 700$ at LT to $\sim 1200$ diggers at Wx (Table 3). The mean estimated catch per fishing session varied according to the studied site from $\sim 21$ lugworms at FM to $\sim 40$ lugworms at Wx (Table 3). Since no value was available at $\mathrm{Au}$, we used the mean value of the three other studies sites giving $~ 31$ lugworms per tide and per recreational fisherman (Table 3). The estimated number of dug lugworms at the studied sites ranged from $\sim 6000$ lugworms at FM to more than $\sim 110000$ Arenicola spp. at $\mathrm{Au}$ which led to a retail value varying between $\sim 3000 €$ at FM to more than $\sim 49000 €$ at $\mathrm{Au}$ in 2015 (Table 3). The total retail value of recreational arenicolid fisheries within the MPA (232 $447 €$ ) appeared to be about the equivalent to the retail value of the recreational shrimp Crangon crangon fisheries (215 714 to $414727 €$ ), and only 4 to 5 times less important than the one of the recreational mussel Mytilus edulis fisheries (1 $203449 €$ ) (Table $3)$.

\subsection{Linking lugworms' life-history traits to bait collection data}

At the four studied sites, the number of lugworms above $3 \mathrm{~g}$ (e.g. considered as valuable by fishermen (Olive, 1993)) ranged between $\sim 700000$ Arenicola spp. at FM to $\sim 1300000$ Arenicola spp. at Wx (Table 3, Fig. 6). In 2015, the number of lugworms dug by recreational fishermen represented respectively $3.6 \%$ of the number of lugworms (both species combined) greater than $3 \mathrm{~g}$ at $\mathrm{Wx}, 2.9 \%$ at LT, $0.9 \%$ at FM, and $13.9 \%$ at $\mathrm{Au}$, and respectively $0.8 \%$ of the total number of lugworms (both species combined) at Wx, $2.9 \%$ at LT, $0.9 \%$ at FM, and $13.7 \%$ at $\mathrm{Au}$ (Fig. 6). At Au only, the number of dug lugworms for the year 2015 (117 791 lugworms) was greater than the estimated abundance of A. marina (12 810 lugworms in total, all weights considered), only considering recreational fisheries (Fig. 6). 
3.1. Species identification, abundances and spatial distribution

421 Our results confirmed the occurrence of both Arenicola marina and A. defodiens on the 422 French coast of the Eastern English Channel, only mentioned by Müller (2004) while other 423 authors only reported A. marina in ecological studies (e.g. Rolet et al., 2014) and may have 424 been confusing the two species, especially in sites where they live in sympatry on the same level of the shore (on the lower shore). However, since $A$. defodiens burrows deeper into the sand, it is therefore harder to collect and previous studies may have failed in collecting this latter species, for which only bait pumps proved to be efficient. Until now, A. defodiens has only been described in the UK, the Netherlands and Portugal (Atlantic Ocean). In this study, we have shown the evidence of the occurrence of $A$. defodiens on the French coast of the Eastern English Channel, suggesting that this species is widely distributed on the whole French coast of both the English Channel and the Atlantic Ocean.

The maximum abundance of Arenicola marina found in this study at Wx (61 individuals. $\mathrm{m}^{-2}$ ) was comparable to those found in other studies in the Wadden Sea and Portugal ( $\sim 40$ to 70 individuals. $\mathrm{m}^{-2} \max$ ) (Beukema and De Vlas, 1979; Flach and Beukema, 1994; Pires et al., 2015) but did not reach the highest abundance recorded by Farke et al. (1979) (more than 150 individuals. $\mathrm{m}^{-2}$ ). In comparison, the values found at LT and FM for this species (2.7 and 0.6 individuals. $\mathrm{m}^{-2}$ max respectively) appeared relatively low. This discrepancy may be linked to physical disturbances within the higher shore at these two sites caused by mechanical engines that remove debris deposited by the tide. Beukema (1995) showed that repeated mechanical harvest of lugworms using digging machines similar to what is present at LT and FM, could decrease the overall densities of worms. In these two sites no recruits were observed during the spring period and only few individuals were collected on the higher shore during the autumn. Some individuals of $A$. marina may have migrated on the lower shore, on the EUNIS habitat A2.23 (medium to fine sands with amphipods and Scolelepis sp.) or even on the EUNIS habitat A5.231 (medium to fine sands with Donax vittatus), as lugworms may do during cold winters (Wolff and de Wolf, 1977). The trade-off made by sharing the same ecological niche with $A$. defodiens on the lower shore at FM and LT involves interspecific competition for food and habitat, higher predation rate by birds and flatfish. This would make the survival rate of $A$. marina lower, and consequently decrease its abundance in comparison with sites where $A$. marina could live not in sympatry with $A$. defodiens such as at Wx. For $A$. 
452

453

454

455

456

457

458

459

460

461

462

463

464

465

466

467

468

469

470

471

472

473

474

475

476

477

478

479

480

481

482

483

484

higher to what Pires et al. (2015) found in Portugal (between 0.25 and 1 individual. $\mathrm{m}^{-2}$ ). The similar abundance of $A$. defodiens observed at all sites might be linked to the presence of a subtidal population of this species: when, for some reason, densities of population from the foreshore decrease, the subtidal individuals could colonize the empty spaces and reload the intertidal $A$. defodiens population. Indeed, the subtidal presence of $A$. defodiens was recorded in Portugal by Pires et al. (2015) and in France on the Eastern English Channel by the present authors (unpublished data). However, the density estimation for A. defodiens was made from data of cast production obtained for A. marina, and further investigation on the cast production of $A$. defodiens is needed to conclude more accurately on the abundance of this species.

\subsection{Life-history traits of lugworm}

The spawning period of Arenicola marina appeared to occur at the beginning of autumn and at the end of autumn to beginning of winter (at Wx) for $A$. defodiens. There was a time lag of two weeks to two months between the two species' spawning periods, as previously described by several authors (Dillon and Howie, 1997; Watson et al., 1998, 2000), probably to avoid species hybridization which was shown to be possible by in vitro fertilization (Watson et al., 2008). For both species, spawning periods vary according to the year. Environmental parameters such as tidal amplitude cycles, temperature (temperature at the beginning of the gametogenesis and temperature just prior to spawning) as well as weather conditions have shown to influence spawning periods in A. marina (Watson et al., 2008, 2000). The combination of these environmental parameters may explain the variation of spawning periods between years. In fact, spawning periods recorded in this study for both species are likely to have occurred during spring tides (Supplementary Material: Fig. H), but not at the same water temperature. There was $\sim 4^{\circ} \mathrm{C}$ difference between the minimum and the maximum of water temperature during the spawning period of the different sites for a respective species which might suggest that spring tides may play a role in the triggering of spawning events rather than water temperature. Watson et al. (2000) suggested for a Scottish population of $A$. marina that others spawning cues may be taken into account such as air temperature, air pressure, daily rainfall and/or wind speed, etc.

The size at first maturity found for Arenicola marina at Wx $(3.8 \mathrm{~cm})$ corresponds to an individual of approximately $1 \mathrm{~g}$, which is close to the weight at which individuals of $A$. marina started developing gametes in the laboratory experiment performed by De Wilde and Berghuis (1979). Recruits of A. marina were only spotted at Wx and recruitment happened 
between the end of spring and the beginning of summer, which mirrored recruitment period recorded by Flach and Beukema (1994). No recruits of $A$. marina were detected on the other sites. Since sampling for spatial distribution pattern was performed at the beginning of spring at LT and FM, we might have come too early to detect recruitment of the first cohort of $A$. marina on these sites and further investigation will be needed since some small individuals were then detected on the upper shore in autumn 2016 at both sites. However, another possible explanation to the uneven distribution and abundance of $A$. marina recorded at the different sites might be explained by a particularly low survival rate of the recruits at LT, FM, and Au compared to $\mathrm{Wx}$, due to physical disturbance as mentioned earlier. Another hypothesis is linked to the lifecycle of $A$. marina that involves a post-larval nursery grounds composed of sheltered soft sediments, macro-algae and/or mussel beds (Farke and Berghuis, 1979b; Reise, 1985). These transitory colonization habitats might have been degraded by anthropogenic disturbance at $\mathrm{Au}$ (Paute, 2015) or naturally absent close to LT and FM (as suggested by the subtidal macrobenthic community map for the area designed by Croguennec et al. (2011)), enhancing a post-larval mortality and subsequently a low recruitment of juveniles on the beach after the second larval dispersal phase. The low recruitment of $A$. marina at LT, FM and Au might also be linked again to the two phases of dispersal during its lifecycle, where, under certain weather conditions, a strong current may be directed up North (Bailly Du Bois et al., 2002; Ellien et al., 2000; Nicolle et al., 2017) during the second dispersal phase prior to the settlement of juveniles on the higher shore, favoring recruitment to North sites such as Wx (which could be considered as a sink of propagules) compared to the three others sites that are more south on the MPA (which could rather be considered as sources of propagules). Further studies on larval dispersal using a modeling approach based on biophysical model or population genetics should be applied to support this hypothesis.

3.3. Linking life-history traits, abundance and spatial distribution to bait collection data: management stakes and fishery

At Wx, LT and FM, according to the survey carried out in 2015 on recreational fishermen, extraction levels of lugworms appeared quite low compared to the lugworm abundances calculated in this study (less than $5 \%$ of the population harvested). Moreover, the presence of numerous young individuals of $A$. marina at Wx seems to ensure a rapid renewal of the part of the population allocated to bait digging. However, 104 professional licenses have been delivered to some fishermen specialized in lugworm digging within the MPA and some of them are able to extract more than 400 worms per tide (anonymous fisherman 
communication). The lugworm extraction may have been underestimated in this study as the survey was done only on recreational fishermen. Besides, the proportion of the lugworm population dug at Au was already quite high (13.7\% of the total number of individuals and $13.9 \%$ of the individuals heavier than $3 \mathrm{~g}$ ). If we consider that the maximum age of Arenicola defodiens is close to the one of A. marina, which is around 5 to 6 years old, it means that every year, around one sixth to one fifth (e.g. $17 \%$ to $20 \%$ ) of the population is renewed (Beukema and De Vlas, 1979). In this case, maybe the managers of the MPA should consider following up the population's density of this species to make sure that its abundance does not decrease over time. If so, some preventive management measures should be implemented such as forbidding or restricting the bait collection during the spawning periods and giving a minimum size limit of worm collection. Again, the numbers of $A$. marina were really low at $\mathrm{Au}$ compared to the total number of dug individuals, and actions should be taken to follow up and manage this species in order to allow its recovery. The species was found to be able to produce gametes (adult) between the cohort 2 and 3 (1.5 to 2.5 years old and approximately 1 g) and managers should encourage local fishermen to harvest only lugworms from cohorts 4 or 5 (i.e. worms that spawned at least once, older than 3 years old), where worms are larger to $6.15 \mathrm{~cm}$ long (TL) and getting close to $3 \mathrm{~g}$ (Fig. 3c). Although, further study of the dynamics of population of this studied site is needed to determine the best "size limit" management strategy (Gwinn et al., 2015), especially since the weight/size/age relationships of $A$. marina were only studied at Wx, where the growth of the individuals of this species might be different from the one of the individuals of the same species at Au. However, as mentioned before, Au might not be a sink of larvae of A. marina. A second hypothesis is due to the natural mussels' beds of this site that is not in a good status and may lead to a mortality of the first settlers during their lifecycle (Reise, 1985; Paute, 2015). These last considerations enlighten the need for an integrated management of the different activities, species and

\section{3 habitats in the area.}

544 The total retail value of recreational fisheries for Arenicola spp. within the MPA appeared to 545 be about equivalent to the one of the shrimp Crangon crangon, and only 4 to 5 times less 546 important than the one of the mussel Mytilus edulis (in terms of recreational fisheries). These last two species benefit within the MPA from a number of catch restrictions (length and bags limits, closing fishing areas, restrictions on catch engines, etc.) (Direction interrégionale de la mer Manche Est-mer du Nord, 2015), when no restriction exists for Arenicola spp. recreational fisheries within the MPA. 
551 In order to give restrictions, distinguishing the two species of lugworms will be necessary, 552 and especially, when sympatry of the two species occurs. Pires et al. (2015) suggested that

553 there could be a difference in the shape of the faecal casts, where the faecal casts of $A$.

554 defodiens are more spiral-like than those of $A$. marina. These features could be taught to 555 anglers when fishing for one of the two species must be limited. If size limit of the bait will be 556 needed, size of the cast diameter of the lugworms may be used as an indicator, as this has 557 been well correlated with the size of the worm itself such as in A. marina (Olive, 1993; 558 unpublished data). Again, this information could be communicated to fishermen through 559 education (Watson et al., 2015).

560 To conclude, the management of the lugworm populations within the MPA and some fishery 561 regulation appear crucial given their ecological and economical importance with some 562 populations (e.g. $\mathrm{Au}$ ) that may be threatened by human activities.

\section{Acknowledgements}

565 This work was funded by the Life + Pêche à pied de loisirs Project through the Aires Marines 566 Protégées (EU). This work was also funded by the UPMC, the CNRS and the University of 567 Lille 1. L. De Cubber is funded by a PhD studentship from the University of Lille. We would 568 like to thank C. Rolet for her expertise in Taxonomy to confirm the identification of the 569 species allowing the description of the EUNIS habitats and A. Meirland for interesting 570 discussion regarding the impact of recreational fisherman on lugworms' populations. 


\section{References}

Bailly Du Bois, P., Germain, P., Rozet, M., Solier, L., 2002. Water masses circulation and residence time in the Celtic Sea and English Channel approaches, characterisation based on radionuclides labelling from industrial releases, in: Borretzen, P., Jolle, T., Strand, P. (Eds.), Proceedings from the International Conference on Radioactivity in Environment. Monaco, pp. 395-399.

Beukema, J.J., 1995. Long-term effects of mechanical harvesting of lugworms Arenicola marina on the zoobenthic community of a tidal flat in the Wadden Sea. Netherlands J. Sea Res. 33, 219-227. https://doi.org/10.1016/0077-7579(95)90008-X

Beukema, J.J., De Vlas, J., 1979. Population parameters of the lugworm Arenicola marina living on tidal flats in the Dutch Wadden Sea. Netherlands J. Sea Res. 13, 331-353. https://doi.org/10.1016/0077-7579(79)90010-3

Beverton, R.J.H., Holt, S.J., 1957. On the dynamics of exploited fish populations, Fisheries Investigations Series 2: Sea Fisheries. Springer Netherlands 1993. https://doi.org/10.1007/BF00044132

Blake, R.W., 1979. Exploitation of a natural population of Arenicola marina (L.) from the North-East Coast of England. J. Appl. Ecol. 16, 663-670. https://doi.org/10.2307/2402843

Cadman, P.S., 1997. Distribution of two species of lugworm (Arenicola) (Annelida: Polychaeta) in South Wales. J. Mar. Biol. Assoc. U.K. 77, 389-398. https://doi.org/10.1017/S0025315400071745

Cadman, P.S., Nelson-Smith, A., 1993. A new species of lugworm: Arenicola defodiens sp. nov. mar. biol. Ass. U.K 73, 213-223. https://doi.org/10.1017/S0025315400032744

Cadman, P.S., Nelson-Smith, A., 1990. Genetic evidence for two species of lugworm (Arenicola) in South Wales. Mar. Ecol. Prog. Ser. 64, 107-112.

Cassier, P., Laffont, R., Porchet, M.D., Soyez, D., 1997. La reproduction des invertébrés : stratégies, modalités et régulation : intérêt fondamental et appliqué. Masson.

Clarke, L.J., Hughes, K.M., Esteves, L.S., Herbert, R.J.H., Stillman, R.A., 2017. Intertidal invertebrate harvesting : a meta-analysis of impacts and recovery in an important waterbird prey resource. Mar. Ecol. Prog. Ser. 584, 229-244. 
Croguennec, C., Guillaumont, B., Bajjouk, T., Hily, C., Gentil, F., 2011. REBENT - Atlas de cartes d'habitats historiques. Brest.

De Wilde, P.A.W.J., Berghuis, E.M., 1979. Laboratory experiments on growth of juvenile lugworms, arenicola marina. Netherlands J. Sea Res. 13, 487-502.

606 https://doi.org/10.1016/0077-7579(79)90020-6

607

608

609

610

Dillon, M.M., Howie, D.I.D., 1997. Contrasting breeding periodicity of nearby populations of the lugworm, Arenicola marina (Annelida, Polychaeta). Invertebr Reprod Dev 31, 331335. https://doi.org/10.1080/07924259.1997.9672593

Direction interrégionale de la mer, Manche Est-mer du Nord, 2015. Arrêté réglementant l'exercice de la pêche maritime à pied de loisir sur le littoral du département du Nord.

Ellien, C., Thiebaut, É., Barnay, A.S., Dauvin, J.C., Gentil, F., Salomon, J.C., 2000. The influence of variability in larval dispersal on the dynamics of a marine metapopulation in the eastern Channel. Oceanol. Acta 23, 423-442. https://doi.org/10.1016/S03991784(00)00136-5

Fagan, J.D., Nelson, F.E., 2017. Spatial sampling design in the circumpolar active layer monitoring programme. Permafr. Periglac. Process. 28, 42-51. https://doi.org/10.1002/ppp.1904

FAO, 2012. Recreational fisheries, FAO Technical Guidelines for Responsible Fisheries. Rome.

FAO, 2002a. A fishery manager's guidebook: managment measures and their application. Rome.

FAO, 2002b. FISAT II.

Farke, H., Berghuis, E.M., 1979a. Spawning, larval development and migration behaviour of Arenicola marina in the laboratory. Netherlands J. Sea Res. 13, 512-528.

Farke, H., Berghuis, E.M., 1979b. Spawning, larval development and migration of Arenicola marina under field conditions in the western Wadden sea. Netherlands J. Sea Res. 13, 529-535.

Farke, H., de Wilde, P.A.W.J., Berghuis, E.M., 1979. Distribution of juvenile and adult 
Arenicola marina on a tidal mud flat and the importance of nearshore areas for recruitment. Netherlands J. Sea Res. 13, 354-361. https://doi.org/10.1016/00777579(79)90011-5

Flach, E.C., Beukema, J.J., 1994. Density-governing mechanisms in populations of the lugworm Arenicola marina on tidal flats. Mar. Ecol. Prog. Ser. 115, 139-150. https://doi.org/10.3354/meps115139

Folmer, O., Black, M., Hoeh, W., Lutz, R., Vrijenhoek, R., 1999. DNA primers for amplification of mitochondrial cytochrome c oxidase subunit I from diverse metazoan invertebrates. Mol. Mar. Biol. Biotechnol. 3, 294-299.

Gaudron, S.M., Bentley, M.G., 2002. Control of reproductive behaviour in the scale worm Harmothoe imbricata. Invertebr. Reprod. Dev. 41, 109-118. https://doi.org/10.1080/07924259.2002.9652741

Gwinn, D.C., Allen, M.S., Johnston, F.D., Brown, P., Todd, C.R., Arlinghaus, R., 2015. Rethinking length-based fisheries regulations: The value of protecting old and large fish with harvest slots. Fish Fish. 16, 259-281. https://doi.org/10.1111/faf.12053

Hall, T.A., 1999. BioEdit: a user-friendly biological sequence alignment editor and analysis program for Windows 95/98/NT. Nucleic Acids Symp. Ser. 41, 95-98.

Kristensen, E., 2001. Impact of polychaetes (Nereis spp. and Arenicola marina) on carbon biogeochemistry in coastal marine sediments. Geochem. Trans. 2, 92-103. https://doi.org/10.1186/1467-4866-2-92

Kumar, S., Stecher, G., Tamura, K., 2016. MEGA7: Molecular Evolutionary Genetics Analysis Version 7.0 for Bigger Datasets. Mol. Biol. Evol. 33, 1870-1874. https://doi.org/10.1093/molbev/msw054

Li, J., Heap, A.D., 2008. A review of spatial interpolation methods for environmental scientists, Geoscience Australia.

Luttikhuizen, P.C., Dekker, R., 2010. Pseudo-cryptic species Arenicola defodiens and Arenicola marina (Polychaeta: Arenicolidae) in Wadden Sea, North Sea and Skagerrak: Morphological and molecular variation. J. Sea Res. 63, 17-23. https://doi.org/10.1016/j.seares.2009.09.001

McLusky, D.S., Anderson, F.E., Wolfe-Murphy, S., 1983. Distribution and population 
660

661

662

663

664

665

666

667

668

669

670

671

672

673

674

675

676

677

678

679

680

681

682

683

684

685

686

687

688

recovery of Arenicola marina and other benthic fauna after bait digging. Mar. Ecol. Prog. Ser. 11, 173-179.

Migné, A., Spilmont, N., Davoult, D., 2004. In situ measurements of benthic primary production during emersion: seasonal variations and annual production in the Bay of Somme (eastern English Channel, France). Cont. Shelf Res. 24, 1437-1449. https://doi.org/10.1016/j.csr.2004.06.002

Müller, Y., 2004. Faune et flore du littoral du nord, du Pas-de-Calais et de la Belgique. Région Nord Pas-de-Calais: France.

Nicolle, A., Moitié, R., Ogor, J., Dumas, F., Foveau, A., Foucher, E., Thiébaut, E., 2017. Modelling larval dispersal of Pecten maximus in the English Channel: a tool for the spatial management of the stocks. ICES J. Mar. Sci. 74, 1812-1825. https://doi.org/10.1093/icesjms/fsw207

Olive, P.J.W., 1993. Management of the exploitation of the lugworm Arenicola marina and the ragworm Nereis virens (Polychaeta) in conservation areas. Aquat. Conserv. Mar. Freshw. Ecosyst. 3, 1-24. https://doi.org/10.1002/aqc.3270030102

Paute, F.E., 2015. La pêche à pied des moules et des crevettes sur le littoral du Cap Gris Nez au Tréport : effet des pratiques et suivi des ressources. Master's thesis. University Pierre and Marie Curie.

Pires, A., Martins, R., Magalhães, L., Soares, A., Figueira, E., Quintino, V., Rodrigues, A., Freitas, R., 2015. Expansion of lugworms towards southern European habitats and their identification using combined ecological, morphological and genetic approaches. Mar. Ecol. Prog. Ser. 533, 177-190. https://doi.org/10.3354/meps11315

QGIS development team, 2016. QGIS Geographic Information System.

R Core Team, 2017. R: A language and environment for statistical computing.

Reise, K., 1985. Tidal flat ecology - An experimental approach to species interactions, Ecological Studies.

Reise, K., Simon, M., Herre, E., 2001. Density-dependent recruitment after winter disturbance on tidal flats by the lugworm Arenicola marina. Helgol. Mar. Res. 55, 161-165. https://doi.org/10.1007/s101520100076 
Rogers, S.I., 1997. A review of closed areas in the United Kingdom Exclusive Economic Zone. Lowesoft.

Rolet, C., Luczak, C., Spilmont, N., Dewarumez, J.-M., 2014. Map of the benthic communities of the sandy shores of the Eastern English Channel and the Southern Bight of the North Sea (France).

Rolet, C., Spilmont, N., Dewarumez, J.M., Luczak, C., 2015. Linking macrobenthic communities structure and zonation patterns on sandy shores: Mapping tool toward management and conservation perspectives in Northern France. Cont. Shelf Res. 99, 12 25. https://doi.org/10.1016/j.csr.2015.03.002

Romano, C., Voight, J.R., Company, J.B., Plyuscheva, M., Martin, D., 2013. Submarine canyons as the preferred habitat for wood-boring species of Xylophaga (Mollusca, Bivalvia). Prog. Oceanogr. 118, 175-187. https://doi.org/10.1016/j.pocean.2013.07.028

Volkenborn, N., 2005. Ecosystem engineering in intertidal sand by the lugworm Arenicola marina. PhD dissertation. University of Bremen.

Watson, G.J., Cadman, P.S., Paterson, L.A., Bentley, M.G., Auckland, M.F., 1998. Control of oocyte maturation, sperm activation and spawning in two lugworm species: Arenicola marina and Arenicola defodiens. Mar. Ecol. Prog. Ser. 175, 167-176. https://doi.org/10.3354/meps175167

Watson, G.J., Hannah, L.C., Gaudron, S.M., Betteley, K.A., Bentley, M.G., 2008. Extension of the breeding season and its effects on fertilization and development in two species of lugworm (Arenicola marina and A. defodiens). J. Exp. Mar. Bio. Ecol. 354, 17-27. https://doi.org/10.1016/j.jembe.2007.10.002

Watson, G.J., Murray, J.M., Schaefer, M., Bonner, A., 2017a. Bait worms: a valuable and important fishery with implications for fisheries and conservation management. Fish Fish. 18, 374-388. https://doi.org/10.1111/faf.12178

Watson, G.J., Murray, J.M., Schaefer, M., Bonner, A., 2015. Successful local marine conservation requires appropriate educational methods and adequate enforcement. Mar. Policy 52, 59-67. https://doi.org/10.1016/J.MARPOL.2014.10.016

Watson, G.J., Murray, J.M., Schaefer, M., Bonner, A., Gillingham, M., 2017b. Assessing the impacts of bait collection on inter-tidal sediment and the associated macrofaunal and bird 
communities: The importance of appropriate spatial scales. Mar. Environ. Res. 130, 122133. https://doi.org/10.1016/j.marenvres.2017.07.006

721

722

723

724

725

726

727

728

729

730

731

732

733

734

735

736

737

738

739

740

741

742

743

744

Watson, G.J., Williams, M.E., Bentley, M.G., 2000. Can synchronous spawning be predicted from environmental parameters? A case study of the lugworm Arenicola marina. Mar. Biol. 136, 1003-1017. https://doi.org/10.1007/s002270000283

Wolff, W.J., de Wolf, L., 1977. Biomass and production of zoobenthos in the Grevelingen estuary, the Netherlands. Estuar. Coast. Mar. Sci. 5, 1-24. https://doi.org/10.1016/03023524(77)90070-6

Xenarios, S., Queiroga, H., Lillebø, A., Aleixo, A., 2018. Introducing a Regulatory Policy Framework of Bait Fishing in European Coastal Lagoons: The Case of Ria de Aveiro in Portugal. Fishes 3, 2. https://doi.org/10.3390/fishes3010002 
Table 1: Summary of the number of samples and the associated name of the collected species, date, site and type of EUNIS habitat for the assessment of the biological traits of the two lugworm species at Wimereux (Wx), Le Touquet (LT), Fort Mahon (FM) and Ault (Au).

\begin{tabular}{|c|c|c|c|c|c|}
\hline Biological traits & Site & Species* & $\begin{array}{l}\text { Number of } \\
\text { individuals ( } \mathrm{n} \text { ) }\end{array}$ & Type of EUNIS habitat ** & Date \\
\hline Population structure & Wx & Arenicola marina & 186 & A2.223 & May and July 2017 \\
\hline \multirow{8}{*}{ Species distribution } & \multirow{2}{*}{ Wx } & A. marina & 24 & $A 2.223+A 2.23$ & \multirow{2}{*}{ March 2016} \\
\hline & & A. defodiens & 5 & $\mathrm{~A} 2.223+\mathrm{A} 2.23$ & \\
\hline & \multirow{2}{*}{ LT } & A. marina & 4 & $\mathrm{~A} 2.223+\mathrm{A} 2.23$ & \multirow{2}{*}{ April 2016} \\
\hline & & A. defodiens & 1 & $\mathrm{~A} 2.223+\mathrm{A} 2.23$ & \\
\hline & \multirow{2}{*}{ FM } & A. marina & 4 & $\mathrm{~A} 2.223+\mathrm{A} 2.23$ & \multirow{2}{*}{ April 2016} \\
\hline & & A. defodiens & 3 & $\mathrm{~A} 2.223+\mathrm{A} 2.23$ & \\
\hline & \multirow{2}{*}{$\mathrm{Au}$} & A. marina & 1 & $\mathrm{~A} 2.23$ & \multirow{2}{*}{ May and June 2016} \\
\hline & & A. defodiens & 11 & $\mathrm{~A} 2.23$ & \\
\hline \multirow{7}{*}{ Spawning period } & \multirow[b]{2}{*}{ Wx } & A. marina & $\begin{array}{l}51 \\
86\end{array}$ & A2.223 & $\begin{array}{l}\text { Sept - Nov } 2015 \\
\text { Sept - Oct } 2016\end{array}$ \\
\hline & & A. defodiens & $\begin{array}{l}34 \\
16\end{array}$ & A2.23 & $\begin{array}{l}\text { Sept } 2015 \text { - Jan } \\
2016 \\
\text { Oct } 2016 \text { - Dec } 2016\end{array}$ \\
\hline & \multirow{2}{*}{ LT } & A. marina & $\begin{array}{l}17 \\
8 \\
\end{array}$ & $A 2.23+A 2.223$ & $\begin{array}{l}\text { Oct - Dec } 2015 \\
\text { Oct } 2016\end{array}$ \\
\hline & & A. defodiens & $\begin{array}{l}16 \\
12\end{array}$ & A2.23 & $\begin{array}{l}\text { Oct - Dec } 2015 \\
\text { Nov } 2016\end{array}$ \\
\hline & \multirow{2}{*}{$\mathrm{FM}$} & A. marina & $\begin{array}{l}5 \\
19\end{array}$ & $A 2.23+A 2.223$ & $\begin{array}{l}\text { Sept - Nov } 2015 \\
\text { Oct } 2016\end{array}$ \\
\hline & & A. defodiens & $\begin{array}{l}17 \\
11\end{array}$ & A2.23 & $\begin{array}{l}\text { Sept - Nov } 2015 \\
\text { Nov } 2016\end{array}$ \\
\hline & $\mathrm{Au}$ & A. defodiens & 26 & A2.23 & Oct - Nov 2015 \\
\hline Size at first maturity & $W x$ & A. marina & 106 & A2.223 & Sept 2017 \\
\hline
\end{tabular}


Table 2: Mean size and number of individuals and separation indices (SI) of every cohort

750 found with the Bhattacharya analysis

\begin{tabular}{llll}
\hline & Mean trunk length $(\mathbf{c m})$ & Number of individuals & SI \\
\hline Cohort 1 & $0.90 \pm 0.37$ & 27 & - \\
\hline Cohort 2 & $2.56 \pm 0.60$ & 36 & 3.42 \\
\hline Cohort 3 & $4.82 \pm 0.55$ & 76 & 3.93 \\
\hline Cohort 4 & $6.15 \pm 0.56$ & 41 & 2.40 \\
\hline Cohort 5 & $8.21 \pm 0.46$ & 14 & 4.04 \\
\hline Total sample & $4.12 \pm 1.93$ & 194 & - \\
\hline
\end{tabular}

751

752

753

754

755

756

757

758

759

760

761

762

763

764

765

766

767

768

769

770

771

772

773 
Table 3: Extrapolated number of dug worms (per site and on the whole MPA) and its associated retail value, and comparison with the two other major recreational fisheries of the area: Mytilus edulis and Crangon crangon, with Wx for Wimereux, LT for Le Touquet, FM for Fort Mahon, and Au for Au.

\begin{tabular}{|c|c|c|c|c|c|c|c|c|c|}
\hline & $\begin{array}{l}\text { Sites I } \\
\text { Species }\end{array}$ & $\begin{array}{l}\text { Extraction } \\
\text { area } \\
\left(\mathrm{km}^{2}\right)\end{array}$ & $\begin{array}{l}\text { Estimated } \\
\text { number } \\
\text { of fishing } \\
\text { sessions / year } \\
\left({ }^{*}\right)\end{array}$ & $\begin{array}{l}\text { Mean } \\
\text { estimated } \\
\text { catch / fishing } \\
\text { session }\left(^{*}\right)\end{array}$ & $\begin{array}{l}\text { Estimated } \\
\text { removed } \\
\text { number }\end{array}$ & $\begin{array}{l}\text { Estimated } \\
\text { removed weight } \\
\text { (kg) }\end{array}$ & Retail Price & $\begin{array}{l}\text { Total retail } \\
\text { value }(€)\end{array}$ & References \\
\hline \multirow{4}{*}{$\begin{array}{l}\text { Studied } \\
\text { sites } \\
\text { (Arenicola } \\
\text { spp.) }\end{array}$} & Wx & 0.9 & $1246 \pm 40$ & $39.8 \pm 32.1$ & $49590 \pm 19755$ & $198 \mathrm{~kg}$ to 744 & \multirow{4}{*}{$\begin{array}{l}4.19 € / 10 \\
\text { worms }\end{array}$} & $\begin{array}{l}20778 \pm 8 \\
277\end{array}$ & \multirow{4}{*}{$\begin{array}{l}\text { https://www.decathlon.fr/catalogue- } \\
\text { sport-appats-vivants-peche-mer.html } \\
\text { https://estamp.afbiodiversite.fr/donnees }\end{array}$} \\
\hline & LT & 1.5 & $692 \pm 39$ & $34.0 \pm 15.2$ & $23528 \pm 5626$ & $353 \mathrm{~kg}$ to 541 & & $9858 \pm 2357$ & \\
\hline & $\mathrm{FM}$ & 1.8 & $311 \pm 32$ & $21.3 \pm 20.5$ & $6624 \pm 6702$ & $86 \mathrm{~kg}$ to 179 & & $2775 \pm 2808$ & \\
\hline & $\mathrm{Au}$ & 1.8 & $3862 \pm 173$ & $30.5 \pm 25.4$ & $117791 \pm 98203$ & 1.885 & & $\begin{array}{l}49354 \pm 41 \\
147\end{array}$ & \\
\hline \multirow{3}{*}{ Whole MPA } & $\begin{array}{l}\text { Arenicola } \\
\text { spp. }\end{array}$ & - & $18189 \pm 2131$ & $\begin{array}{l}30.5 \pm 25.4 \\
\text { worms }\end{array}$ & $\begin{array}{l}554765 \\
\pm 250323 \text { worms }\end{array}$ & $\begin{array}{l}9875 \\
\pm 4456\end{array}$ & $\begin{array}{l}4.19 € / 10 \\
\text { worms }\end{array}$ & $\begin{array}{l}232447 \\
\pm 105885\end{array}$ & $\begin{array}{l}\text { https://www.decathlon.fr/catalogue- } \\
\text { sport-appats-vivants-peche-mer.html }\end{array}$ \\
\hline & $\begin{array}{l}\text { Mytilus } \\
\text { edulis }\end{array}$ & - & $74287 \pm 3054$ & $3.6 \pm 0.2 \mathrm{~kg}$ & - & $\begin{array}{l}267433 \\
\pm 12280\end{array}$ & $\begin{array}{l}\text { around } 4.5 € / \\
\mathrm{kg}\end{array}$ & $\begin{array}{l}1203449 \\
\pm 55260\end{array}$ & $\begin{array}{l}\text { Local fishermen and } \\
\text { http://www.manger-la-mer.org }\end{array}$ \\
\hline & $\begin{array}{l}\text { Crangon } \\
\text { crangon }\end{array}$ & - & $12652 \pm 1440$ & $1.1 \mathrm{~kg}$ & - & $13917 \pm 1584$ & $\begin{array}{l}15.5 \text { to } 29.8 € / \\
\mathrm{kg}\end{array}$ & $\begin{array}{l}215714 \\
\pm 24552 \\
\text { to } 414727 \\
\pm 47203 \\
\end{array}$ & $\begin{array}{l}\text { FranceAgriMer (2017) and local fish } \\
\text { retailers }\end{array}$ \\
\hline
\end{tabular}


Figure 1. Location of the four studied sites within the MPA where spatial distribution, abundance, life-history traits and survey of bait collection were carried out.

Figure 2. Spatial distributions of the two species Arenicola marina and A. defodiens at the four studied sites: Wimereux (Wx), Le Touquet (LT), Fort Mahon (FM) and Ault (Au), and associated bathymetries (height above chart datum) or distance from the shoreline and EUNIS habitats.

Figure 3. Evolution of the oocyte diameter frequencies of Arenicola defodiens at Wimereux between October 2015 and January 2016, measured on 50 random oocytes of $n$ individuals.

Figure 4. Length-frequency distributions of the trunk lengths of all specimens of Arenicola marina obtained from Wimereux in summer 2017 analysed using FISAT II. Normal curves represent each detected cohort (C.1 to C.5) (A), spatial distribution of the different sizes along the shore level (low $=0.1 \mathrm{~m}$ of bathymetry, medium $=0.9 \mathrm{~m}$ of bathymetry and high $=2.3 \mathrm{~m}$ of bathymetry) (B) and associated length-weight relationship (C). Since recruitment happens once a year at the same period, each cohort represents an age group. Cohort C.1 comprises the newly recruits, born in autumn 2016, C.2 the 1.5 years old individuals, born in autumn 2015 , etc.

Figure 5. Sizes in juveniles and adults of Arenicola marina at Wimereux (A), relative 798 proportion of adults per size class (B) and its associated cumulated frequency (C).

Figure 6. Comparison of the total number of individuals, number of individuals above $3 \mathrm{~g}$ and number of lugworms harvested in 2015 by recreational fishermen respectively for Arenicola marina, A. defodiens, and both species combined at Wimereux (Wx), Le Touquet (LT), Fort Mahon (FM) and Ault (Au). 


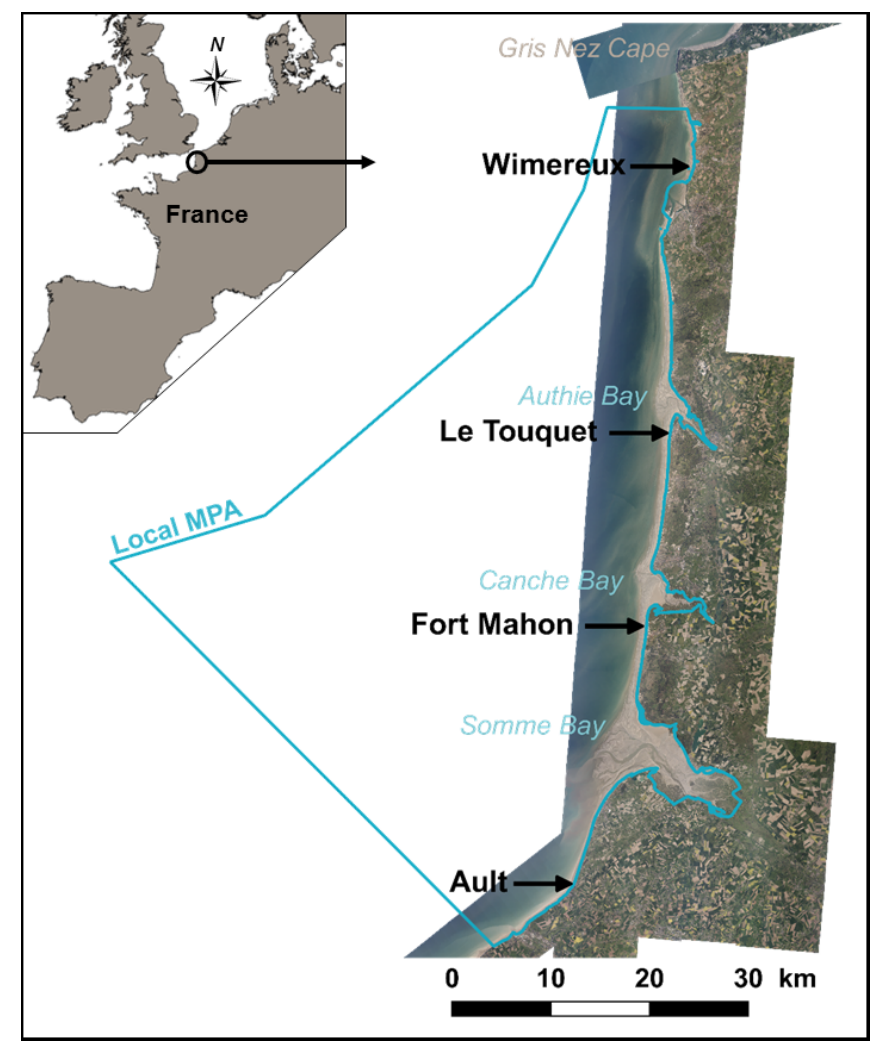




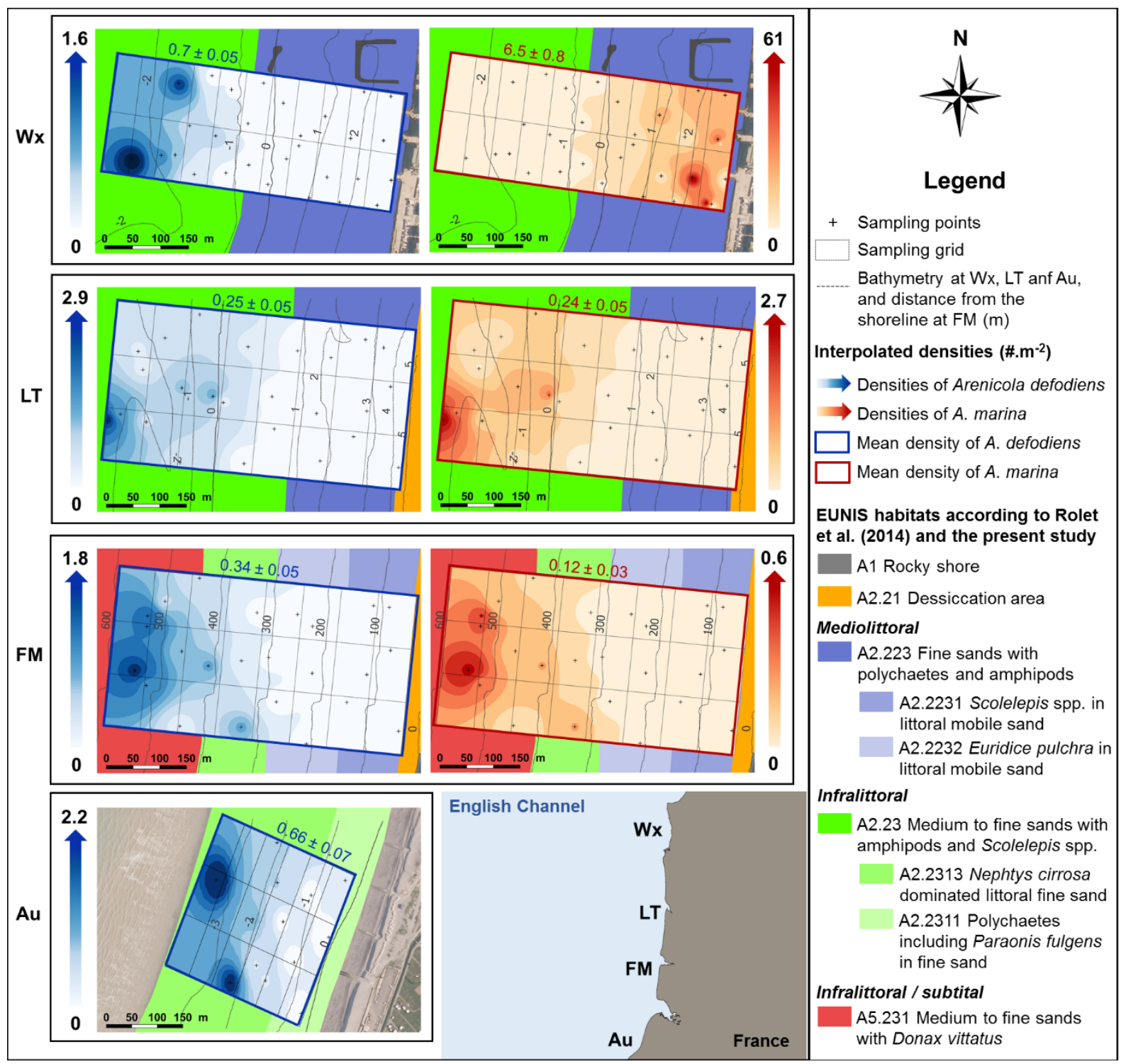




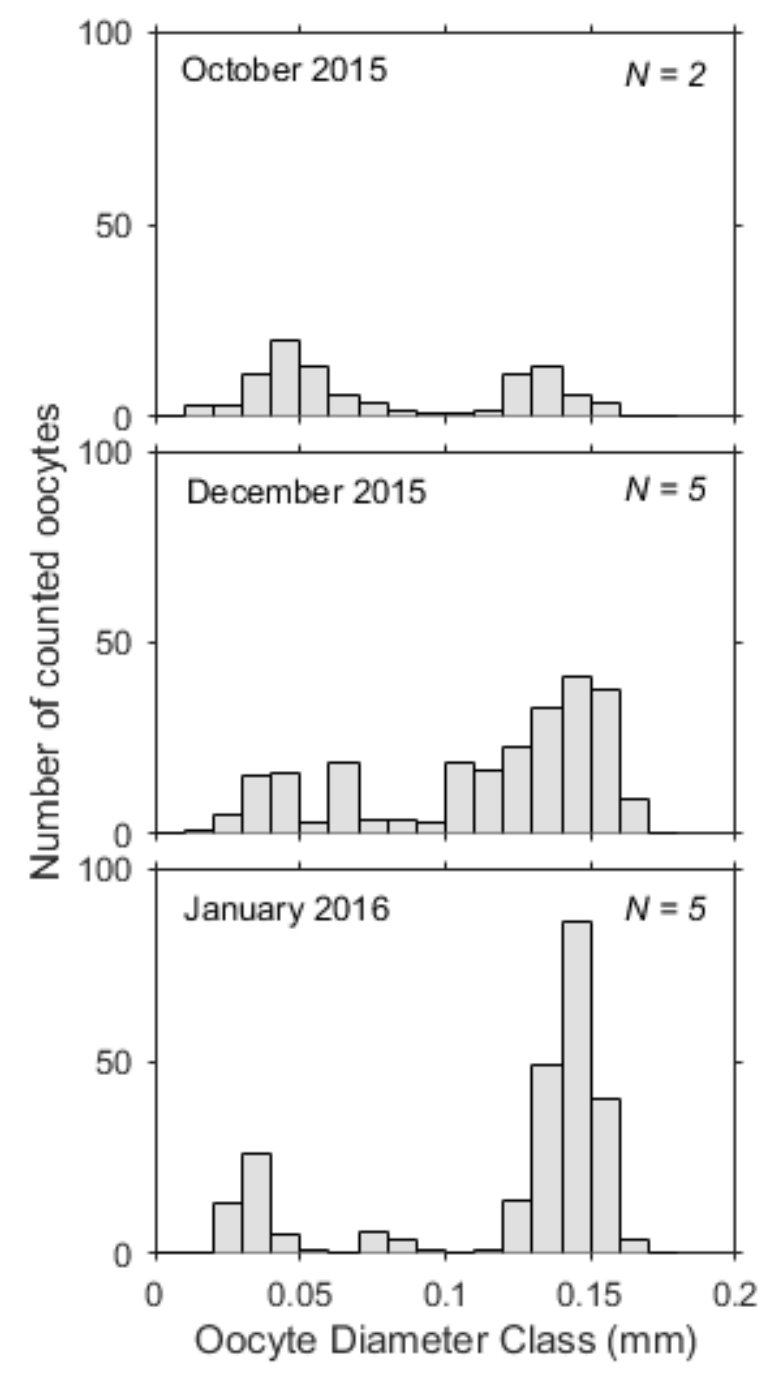



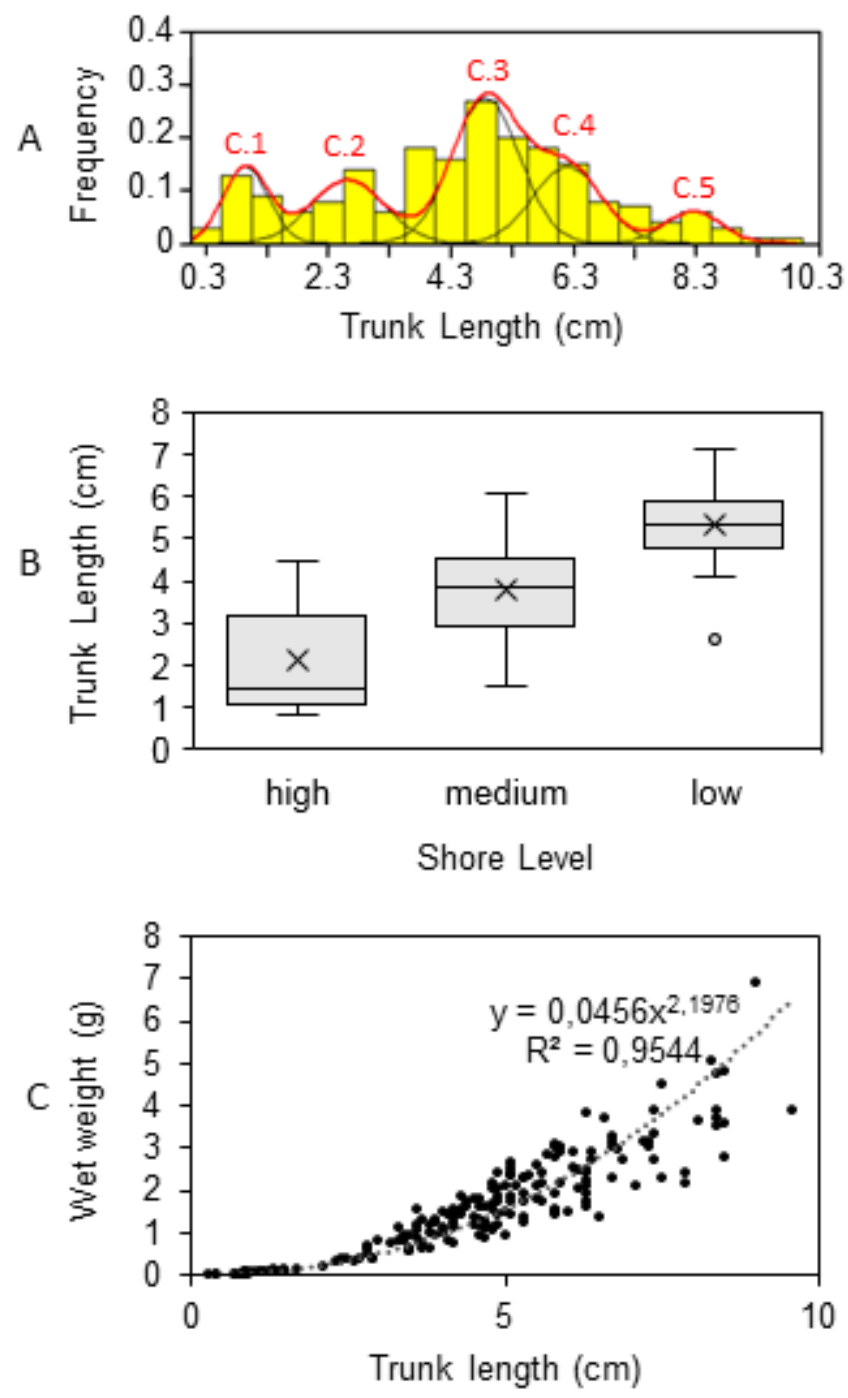

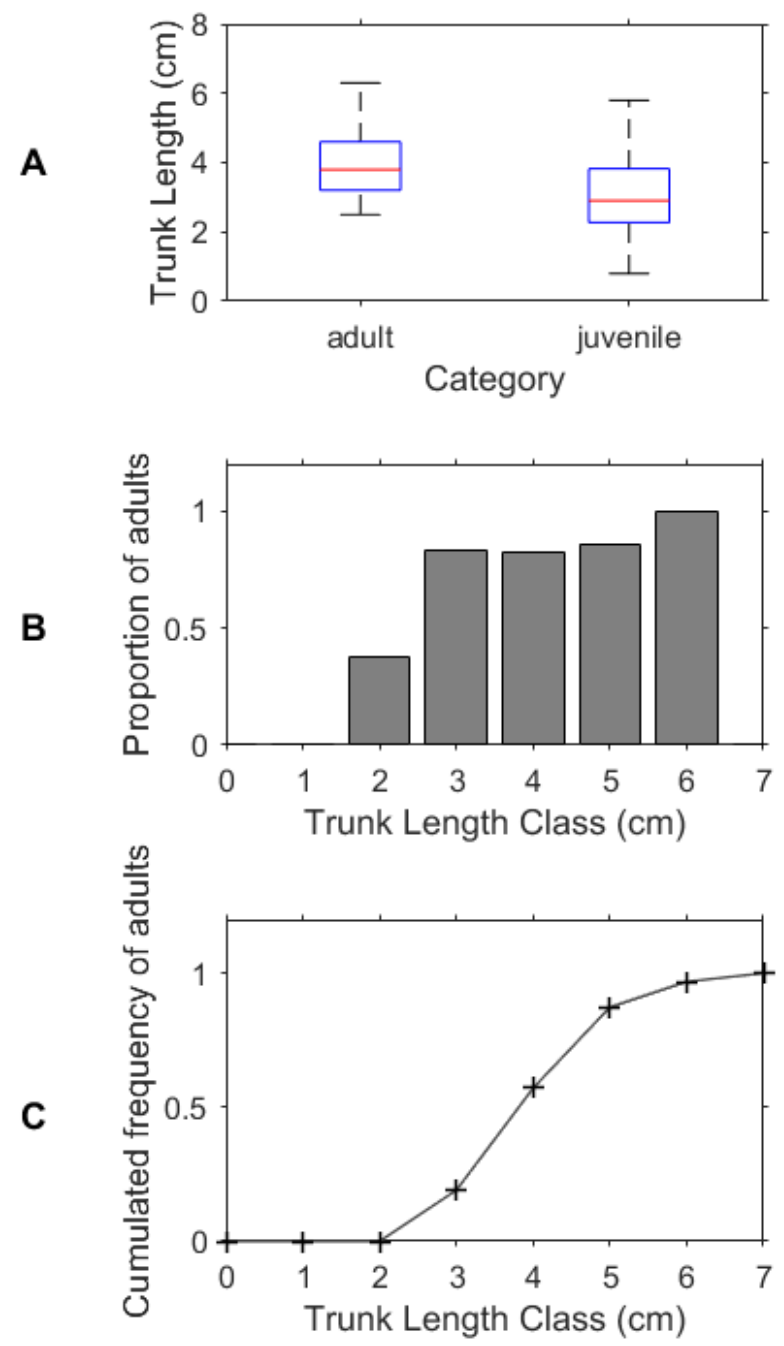

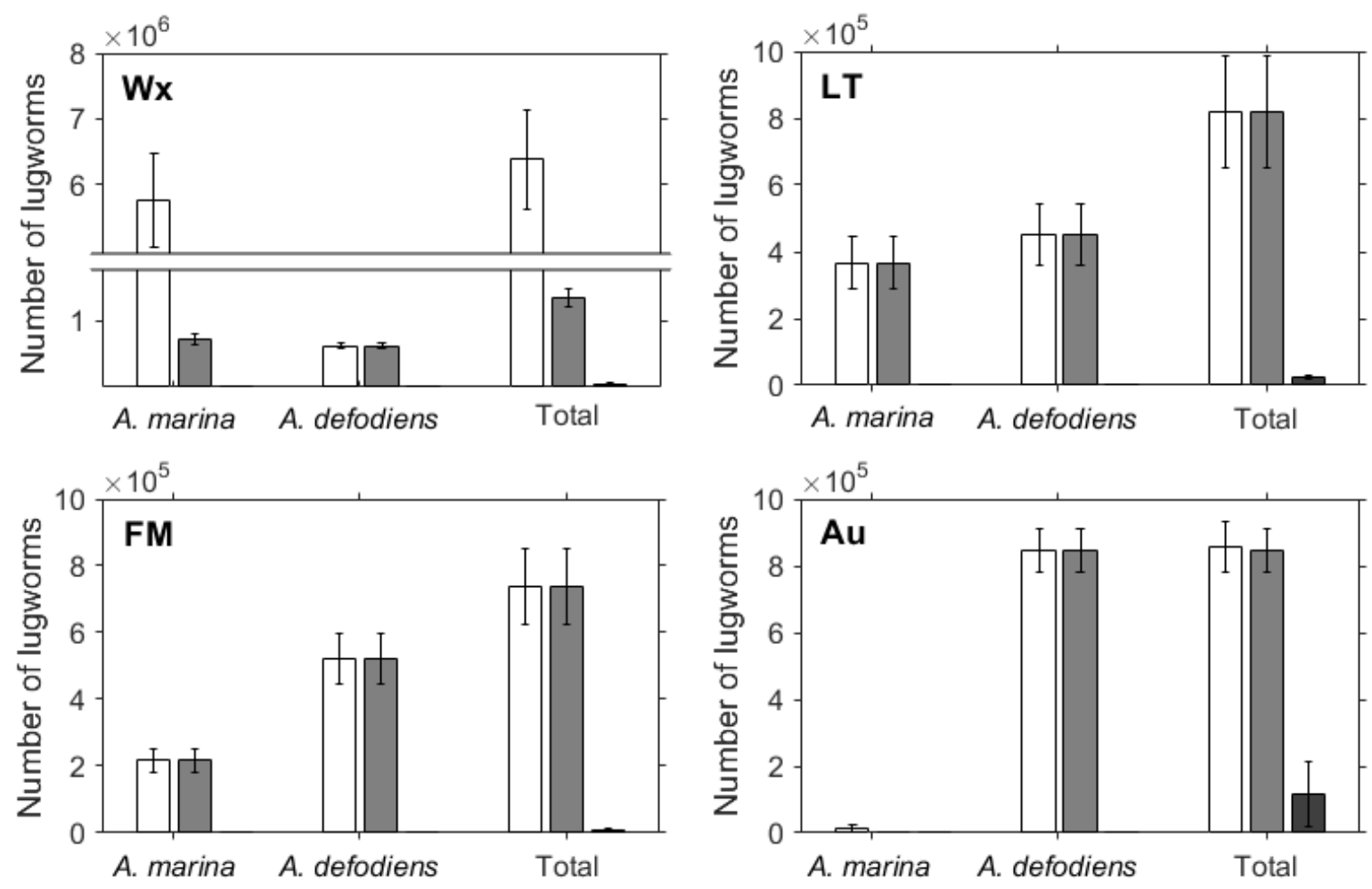

Total number of individuals

Number of individuals above $3 \mathrm{~g}$

Number of lugworms harvested in 2015 
Supplementary Materials 
Table A. COI gene sequences used in the phylogenetic analyses in this study (in bold) and in the literature. For each haplotype, the species, acronym, GenBank accession number, and location (with GPS coordinates when available) are given.

\begin{tabular}{|c|c|c|c|c|c|c|}
\hline Species & Acronym & Genbank accession number & Location & Latitude & Longitude & Literature \\
\hline Arenicola marina & AmAv1P & KM042097 & Ria de Aveiro, Portugal & $40^{\circ} 36^{\prime} 48.76^{\prime \prime} \mathrm{N}$ & $8^{\circ} 44^{\prime} 27.63^{\prime \prime} \mathrm{W}$ & Pires et al., 2015 \\
\hline A. marina & AmAv2P & KM042098 & Ria de Aveiro, Portugal & $40^{\circ} 36^{\prime} 13.29^{\prime \prime} \mathrm{N}$ & $8^{\circ} 44^{\prime} 10.31^{\prime \prime} \mathrm{W}$ & Pires et al., 2015 \\
\hline A. marina & AmR1F & JQ950326 & Roscoff, France & $48^{\circ} 43^{\prime} 40.21^{\prime \prime} \mathrm{N}$ & $3^{\circ} 59^{\prime} 16.21^{\prime \prime} \mathrm{W}$ & Pires et al., 2015 \\
\hline A. marina & AmR2F & JQ950327 & Roscoff, France & $48^{\circ} 43^{\prime} 40.21^{\prime \prime} \mathrm{N}$ & $3^{\circ} 59^{\prime} 16.21^{\prime \prime} \mathrm{W}$ & Pires et al., 2015 \\
\hline A. marina & AmAr1F & HQ023444 & Arcachon, France & $44^{\circ} 39^{\prime} 51^{\prime \prime} \mathrm{N}$ & $1^{\circ} 09^{\prime} 38^{\prime \prime} \mathrm{W}$ & Carr et al., 2011 \\
\hline A. marina & AmAr2F & HQ023443 & Arcachon, France & $44^{\circ} 39^{\prime} 51^{\prime \prime} \mathrm{N}$ & $1^{\circ} 09^{\prime} 38^{\prime \prime} \mathrm{W}$ & Carr et al., 2011 \\
\hline A. marina & AmAr3F & HQ023441 & Arcachon, France & $44^{\circ} 39^{\prime} 51^{\prime \prime} \mathrm{N}$ & $1^{\circ} 09^{\prime} 38^{\prime \prime} \mathrm{W}$ & Carr et al., 2011 \\
\hline A. marina & AmK1R & GU672432 & Kandalaksha Bay, Russia & $66^{\circ} 33^{\prime} 07.2^{\prime \prime} \mathrm{N}$ & $33^{\circ} 6^{\prime} 43.2^{\prime \prime} \mathrm{E}$ & Hardy et al., 2011 \\
\hline A. marina & AmK2R & GU670812 & Kandalaksha Bay, Russia & $66^{\circ} 33^{\prime} 07.2^{\prime \prime} \mathrm{N}$ & $33^{\circ} 6^{\prime} 43.2^{\prime \prime} \mathrm{E}$ & Hardy et al., 2011 \\
\hline A. marina & Amh01NL & GQ487319 & Netherlands & - & - & Luttikhuizen and Dekker, 2010 \\
\hline A. marina & Amh02NL & GQ487320 & Netherlands & - & - & Luttikhuizen and Dekker, 2010 \\
\hline A. marina & Amh03NL & GQ487321 & Netherlands & - & - & Luttikhuizen and Dekker, 2010 \\
\hline A. marina & AmF2F & MF405759 & Fort-Mahon, France & $50^{\circ} 20^{\prime} 24.629 " \mathrm{~N}$ & $1^{\circ} 32^{\prime} 35.286^{\prime \prime} \mathrm{E}$ & This study \\
\hline A. marina & AmF4F & MF405760 & Fort-Mahon, France & $50^{\circ} 20^{\prime} 24.629^{\prime \prime} \mathrm{N}$ & $1^{\circ} 32^{\prime} 35.286^{\prime \prime} \mathrm{E}$ & This study \\
\hline A. marina & AmLT1F & MF405761 & Le Touquet, France & $50^{\circ} 31 ' 12.887^{\prime \prime} \mathrm{N}$ & 1³4'16.803" E & This study \\
\hline A. defodiens & AdAv1P & KM042099 & Ria de Aveiro, Portugal & $40^{\circ} 40^{\prime} 36.70^{\prime \prime} \mathrm{N}$ & $8^{\circ} 40^{\prime} 34.90^{\prime \prime} \mathrm{W}$ & Pires et al., 2015 \\
\hline A. defodiens & AdAv2P & KM042100 & Ria de Aveiro, Portugal & $40^{\circ} 42^{\prime} 43^{\prime \prime} \mathrm{N}$ & $8^{\circ} 40^{\prime} 39^{\prime \prime} \mathrm{W}$ & Pires et al., 2015 \\
\hline A. defodiens & $A d A v 3 P$ & JQ950325 & Ria de Aveiro, Portugal & $40^{\circ} 41^{\prime} 20^{\prime \prime} \mathrm{N}$ & $8^{\circ} 42^{\prime} 54^{\prime \prime} \mathrm{W}$ & Pires et al., 2015 \\
\hline A. defodiens & Adh01NL & GQ487323 & Netherlands & - & - & Luttikhuizen and Dekker, 2010 \\
\hline A. defodiens & Adh02NL & GQ487325 & Netherlands & - & - & Luttikhuizen and Dekker, 2010 \\
\hline A. defodiens & Adh03NL & GQ487324 & Netherlands & - & - & Luttikhuizen and Dekker, 2010 \\
\hline A. defodiens & Adh04NL & GQ487322 & Netherlands & - & - & Luttikhuizen and Dekker, 2010 \\
\hline A. defodiens & AdA01F & MF405762 & Ault-Onival, France & $50^{\circ} 06^{\prime} 45.026^{\prime \prime} \mathrm{N}$ & $1^{\circ} 27^{\prime} 09.686^{\prime \prime} \mathrm{E}$ & This study \\
\hline A. defodiens & AdF1F & MF405763 & Fort-Mahon, France & $50^{\circ} 20^{\prime} 24.629 " \mathrm{~N}$ & $1^{\circ} 32 ’ 35.286^{\prime \prime} \mathrm{E}$ & This study \\
\hline A. defodiens & AdF2F & MF405764 & Fort-Mahon, France & $50^{\circ} 20^{\prime} 24.629^{\prime \prime} \mathrm{N}$ & 1०32'35.286" E & This study \\
\hline
\end{tabular}


1 Figure B. Maximum Likelihood tree of COI sequences of arenicolid species with

2 bootstrapping values. The specimens sequenced in this study are highlighted and acronyms 3 are described in Table A.

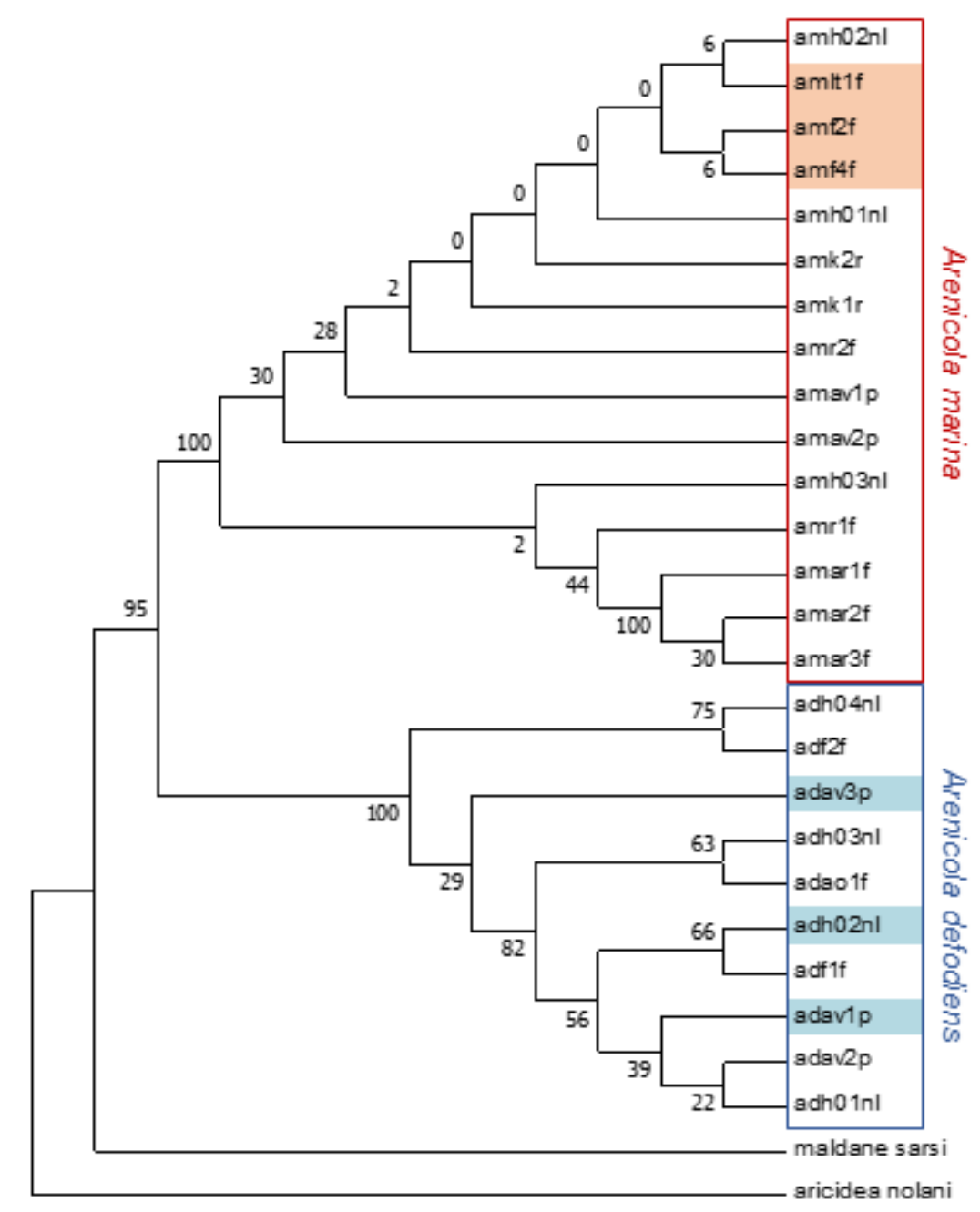


5 Figure C. Linear relation between the number of faecal casts produced and the number of 6 individuals of Arenicola marina.

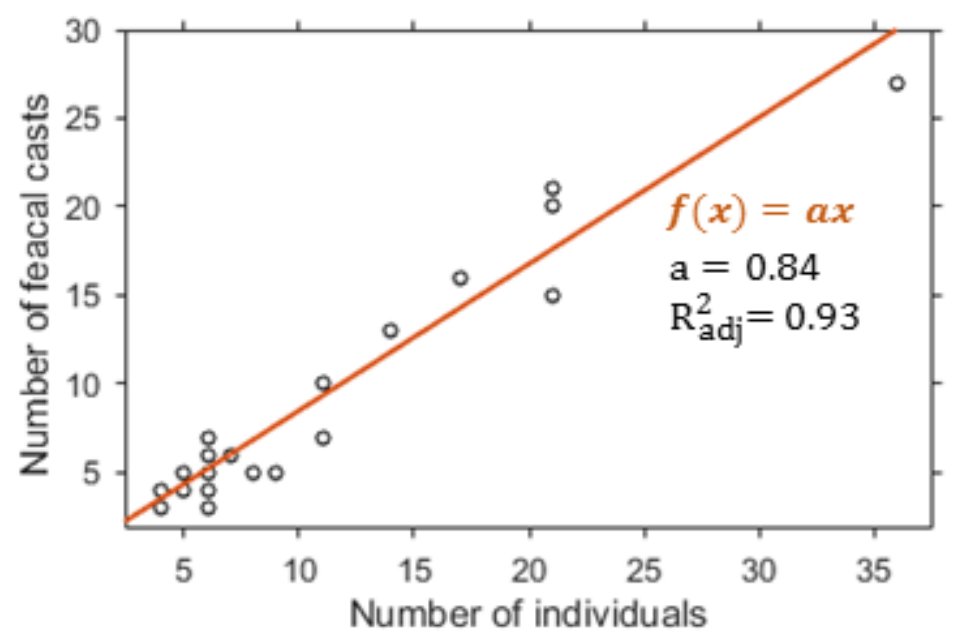

7 
9 Figure D. Proportion of Arenicola marina (red dots) and A. defodiens (blue dots) according to bathymetry at Wimereux and the associated fitting transition curves and functions, as well

11 as the number of lugworms collected at each point to calculate the proportion (weight of the 12 different proportion points).

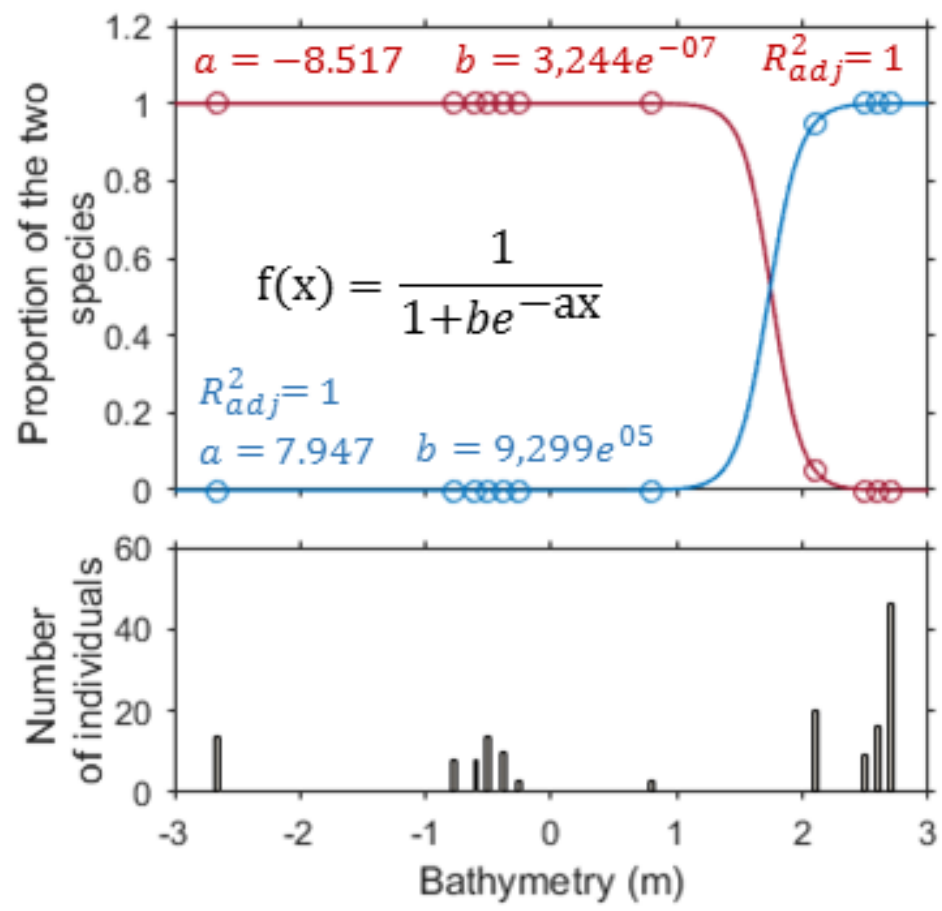


14 Figure E. Proportion of Arenicola marina (red dots) and A. defodiens (blue dots) according 15 to bathymetry or distance from the shoreline and the related number of individuals used to 16 calculate the proportion at Le Touquet (LT) and Fort Mahon (FM).

LT
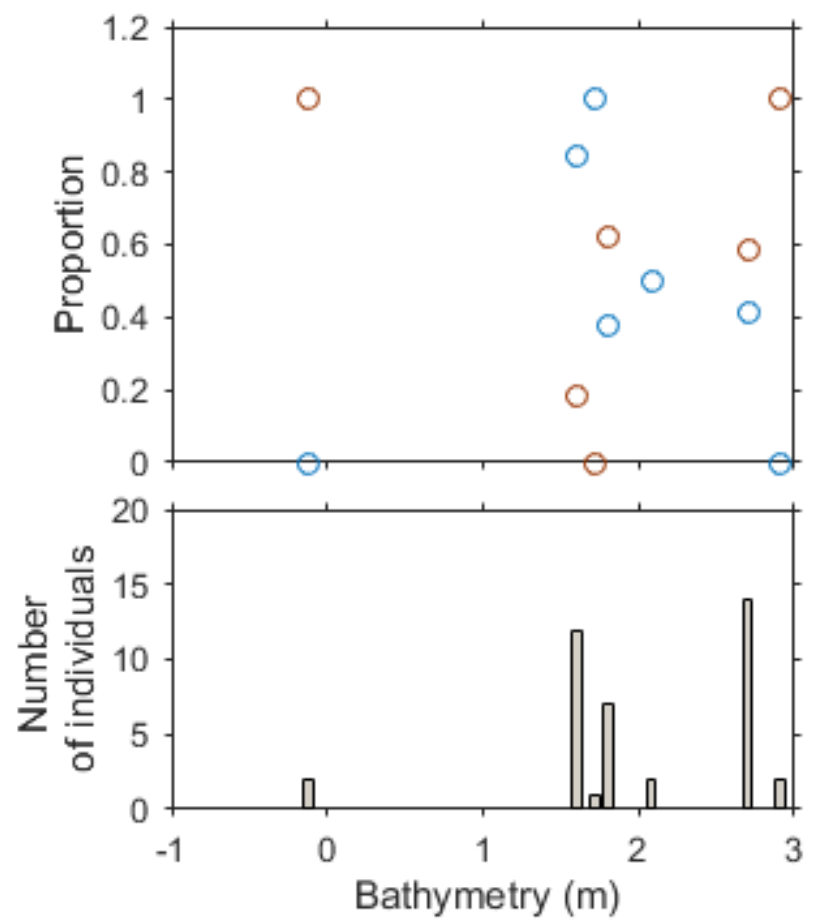

FM
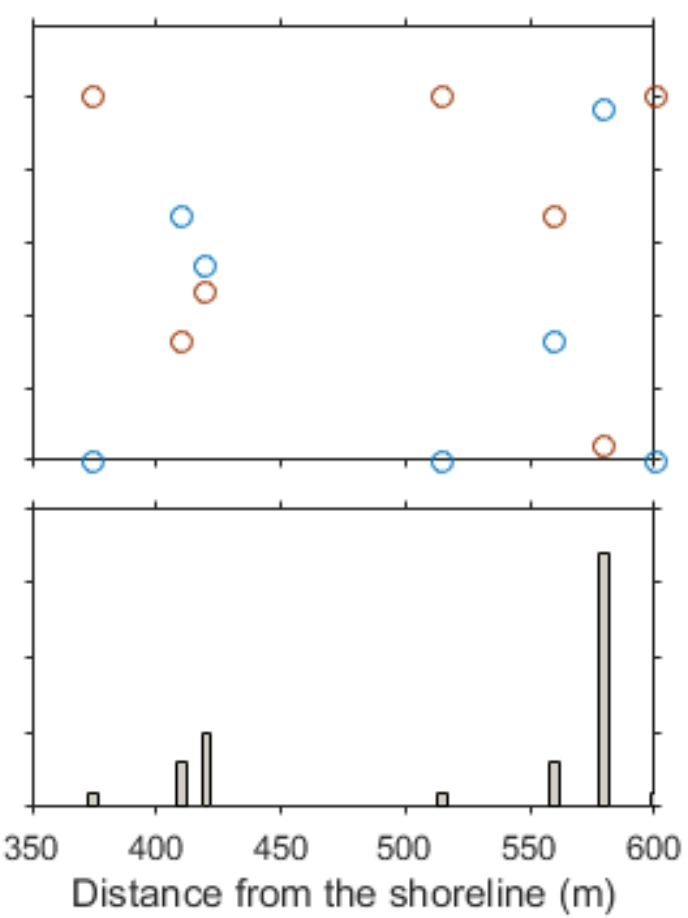
19 Table F. EUNIS habitats found at Fort Mahon and Ault based on particle size analysis and

20 species identification at these sites

\begin{tabular}{|c|c|c|c|c|c|c|}
\hline Site & GPS location & \multicolumn{2}{|l|}{ Species abundancy (\%) } & \multicolumn{2}{|c|}{ Particle size analysis (\%) } & \multirow{14}{*}{$\begin{array}{l}\text { Corresponding } \\
\text { EUNIS habitat } \\
\text { A5.231 Medium } \\
\text { to fine sands with } \\
\text { Donax vittatus }\end{array}$} \\
\hline \multirow{31}{*}{$\begin{array}{l}\text { Fort Mahon } \\
\text { (FM) }\end{array}$} & \multirow{13}{*}{$\begin{array}{c}1^{\circ} 32^{\prime} 31.68^{\prime \prime} \mathrm{E} \\
50^{\circ} 20^{\prime} 24.89^{\prime \prime} \mathrm{N}\end{array}$} & Donax vittatus & 73 & mudstones & 0 & \\
\hline & & Urothoe poseidonis & 10 & fine sands & 70.7 & \\
\hline & & Nephtys cirrosa & 8 & medium sands & 23.6 & \\
\hline & & Spio martinensis & 5 & coarse sands & 1.9 & \\
\hline & & Urothoe brevicornis & 5 & fine gravels & 1.8 & \\
\hline & & Notrotopis falcatus & 4 & coarse gravels & 2.1 & \\
\hline & & $\begin{array}{l}\text { Lanice conchilega } \\
\text { (juveniles) }\end{array}$ & 4 & & & \\
\hline & & Eurydice pulchra & 3 & & & \\
\hline & & Vaunthompsonia cristata & 2 & & & \\
\hline & & Gastrosaccus spinifer & 1 & & & \\
\hline & & Spio sp. & 1 & & & \\
\hline & & Nephtys hombergii & 1 & & & \\
\hline & & Eteone picta & 1 & & & \\
\hline & \multirow{6}{*}{$\begin{array}{c}1^{\circ} 32 \text { '39.03" } \mathrm{E} \\
50^{\circ} 20^{\prime} 24.36^{\prime \prime} \mathrm{N}\end{array}$} & Nephtys cirrosa & 57 & mudstones & 0 & \multirow{6}{*}{$\begin{array}{l}\text { A2.2313 Nephtys } \\
\text { cirrosa dominated } \\
\text { littoral fine sands }\end{array}$} \\
\hline & & Eurydice pulchra & 21 & fine sands & 53.1 & \\
\hline & & Portumnus latipes & 14 & medium sands & 43.6 & \\
\hline & & Nephtys hombergii & 7 & coarse sands & 1.8 & \\
\hline & & & & fine gravels & 1 & \\
\hline & & & & coarse gravels & 0.5 & \\
\hline & \multirow{6}{*}{$\begin{array}{c}1^{\circ} 32^{\prime} 47.60 " \mathrm{E} \\
50^{\circ} 20^{\prime} 23.32^{\prime \prime} \mathrm{N}\end{array}$} & Eurydice pulchra & 60 & mudstones & 0 & \multirow{6}{*}{$\begin{array}{l}\text { A2.2232 Eurydice } \\
\text { pulchra in littoral } \\
\text { mobile sand }\end{array}$} \\
\hline & & Scolelepis squamata & 39 & fine sands & 34.2 & \\
\hline & & Haustorius arenarius & 0.3 & medium sands & 63.5 & \\
\hline & & Urothoe poseidonis & 0.3 & coarse sands & 1.6 & \\
\hline & & Bathyporeia pilosa & 0.3 & fine gravels & 0.5 & \\
\hline & & Nemertean & 0.3 & coarse gravels & 0.2 & \\
\hline & \multirow{6}{*}{$\begin{array}{c}1^{\circ} 32^{\prime} 54.07^{\prime \prime} \mathrm{E} \\
50^{\circ} 20^{\prime} 22.79 " \mathrm{~N}\end{array}$} & Scolelepis squamata & 81 & mudstones & 0 & \multirow{6}{*}{$\begin{array}{l}\text { A2.2231 } \\
\text { Scolelepis spp. in } \\
\text { littoral mobile } \\
\text { sand }\end{array}$} \\
\hline & & Bathyporeia pilosa & 13 & fine sands & 35.4 & \\
\hline & & Carcinus maenas & 2 & medium sands & 62.1 & \\
\hline & & Ophelia rathkei & 2 & coarse sands & 1.4 & \\
\hline & & Haustorius arenarius & 2 & fine gravels & 0.3 & \\
\hline & & & & coarse gravels & 0.7 & \\
\hline \multirow{13}{*}{$\begin{array}{l}\text { Ault } \\
(\mathrm{Au})\end{array}$} & \multirow{3}{*}{$\begin{array}{c}1^{\circ} 27^{\prime} 09.49^{\prime \prime} \mathrm{E} \\
50^{\circ} 06^{\prime} 43.13^{\prime \prime} \mathrm{N}\end{array}$} & Nephtys cirrosa & 50 & mudstones & 0.1 & \multirow{7}{*}{$\begin{array}{l}\text { A2.2313 Nephtys } \\
\text { cirrosa dominated } \\
\text { littoral fine sand }\end{array}$} \\
\hline & & Bathyporeia pelagica & 19 & fine sands & 58.0 & \\
\hline & & & 6 & medium sands & 38.3 & \\
\hline & \multirow{4}{*}{$\begin{array}{c}1^{\circ} 27^{\prime} 04.04^{\prime \prime} \mathrm{E} \\
50^{\circ} 06^{\prime} 44.05^{\prime \prime} \mathrm{N}\end{array}$} & Haustorius arenarius & 6 & coarse sands & 1.9 & \\
\hline & & Nephtys hombergii & 6 & fine gravels & 0.9 & \\
\hline & & Lanice conchilega & 6 & coarse gravels & 0.9 & \\
\hline & & Oligochaete & 6 & & & \\
\hline & \multirow{6}{*}{$\begin{array}{c}1^{\circ} 27^{\prime} 15.07^{\prime \prime} \mathrm{E} \\
50^{\circ} 06^{\prime} 42.31^{\prime \prime} \mathrm{N}\end{array}$} & Paraonis fulgens & 31 & mudstones & 0.1 & \multirow{6}{*}{$\begin{array}{l}\text { A2.2311 } \\
\text { Polychaetes, } \\
\text { including } \\
\text { Paraonis fulgens, } \\
\text { in littoral fine } \\
\text { sand }\end{array}$} \\
\hline & & Gastrosaccus spinifer & 19 & fine sands & 30.8 & \\
\hline & & Eurydice pulchra & 19 & medium sands & 66.3 & \\
\hline & & Nephtys hombergii & 13 & coarse sands & 0.8 & \\
\hline & & Bathyporeia pelagica & 13 & fine gravels & 0.4 & \\
\hline & & Bathyporeia pilosa & 6 & coarse gravels & 1.6 & \\
\hline
\end{tabular}


21 Figure G.1. Oocyte diameter distributions of the collected females of Arenicola marina ( $\mathrm{N}$ is

22 the number of females) at Fort Mahon and Le Touquet in autumn 2015. When boxes appear

23 darker, the sites were not sampled at the corresponding date.
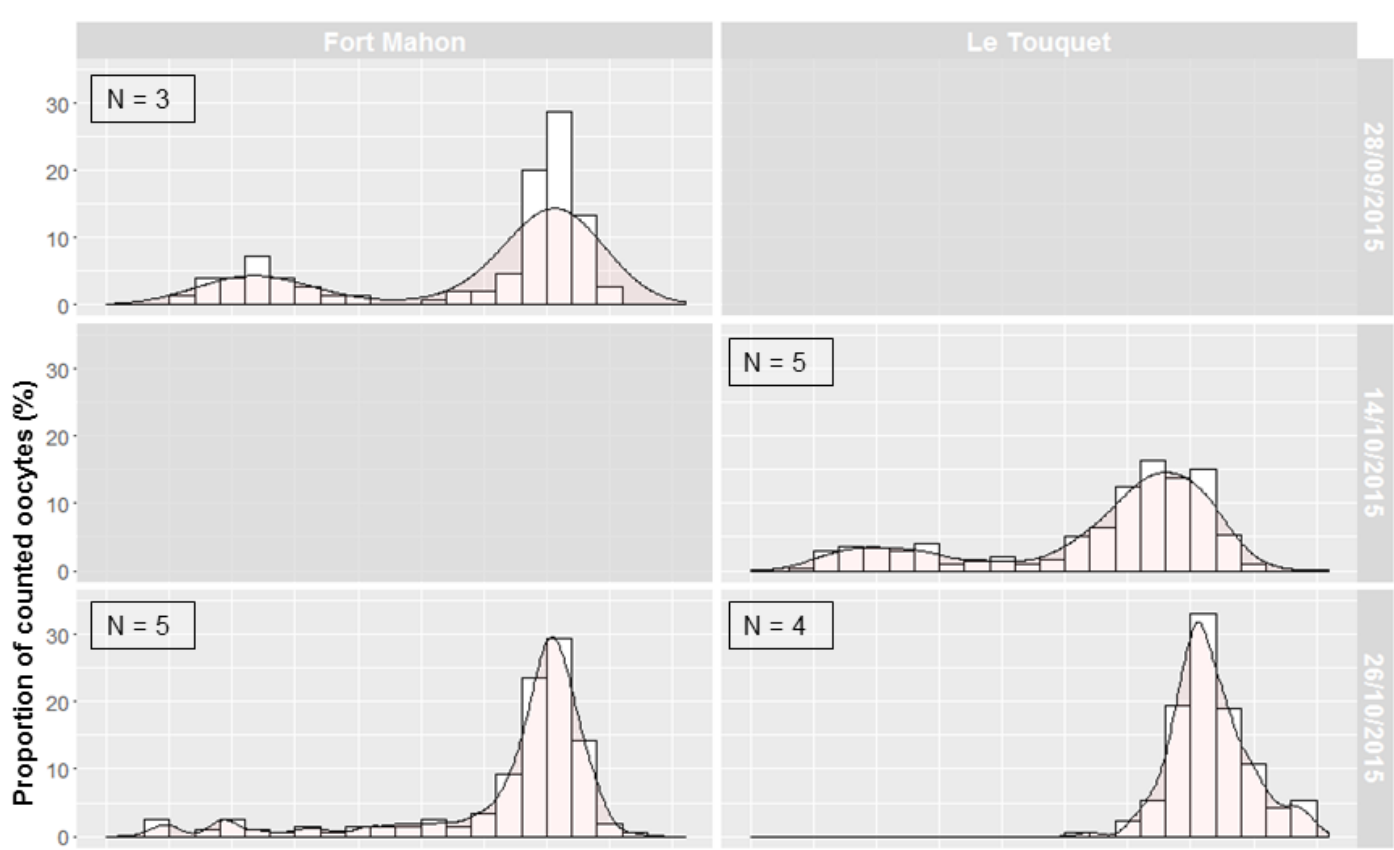

$\mathrm{N}=4$
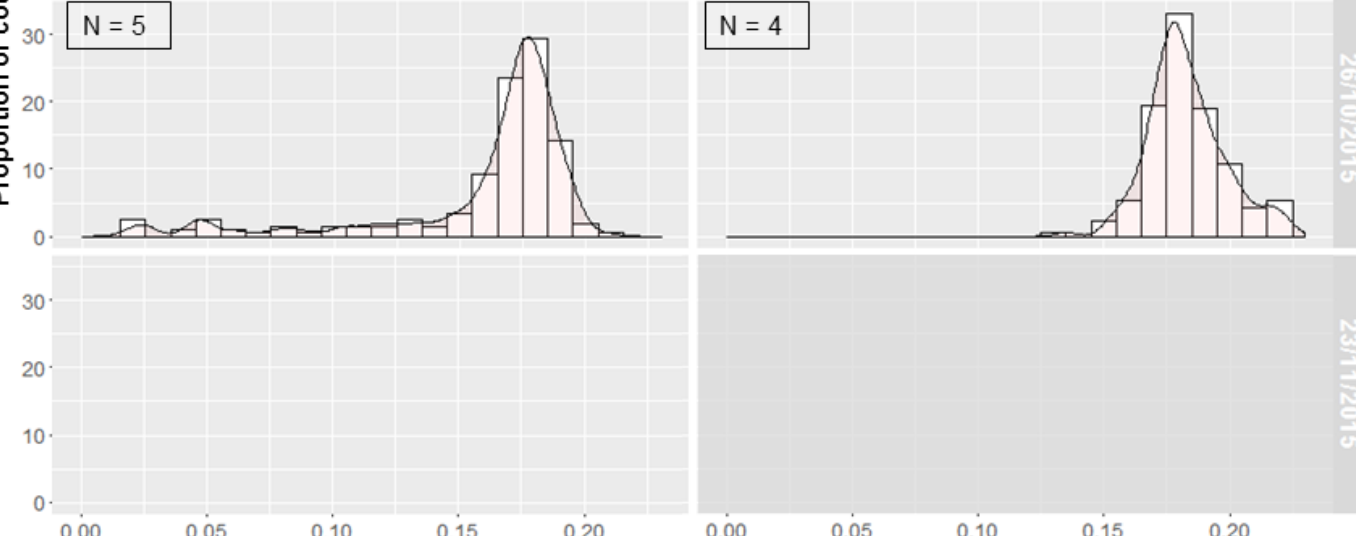

Diameter class $(\mathrm{mm})$ 
25 Figure G.2. Oocyte diameter distributions of the collected females ( $\mathrm{N}$ is the number of

26 females) of Arenicola marina at Fort Mahon, Le Touquet and Wimereux in autumn 2016.

27 When boxes appear, darker the sites were not sampled at the corresponding date.

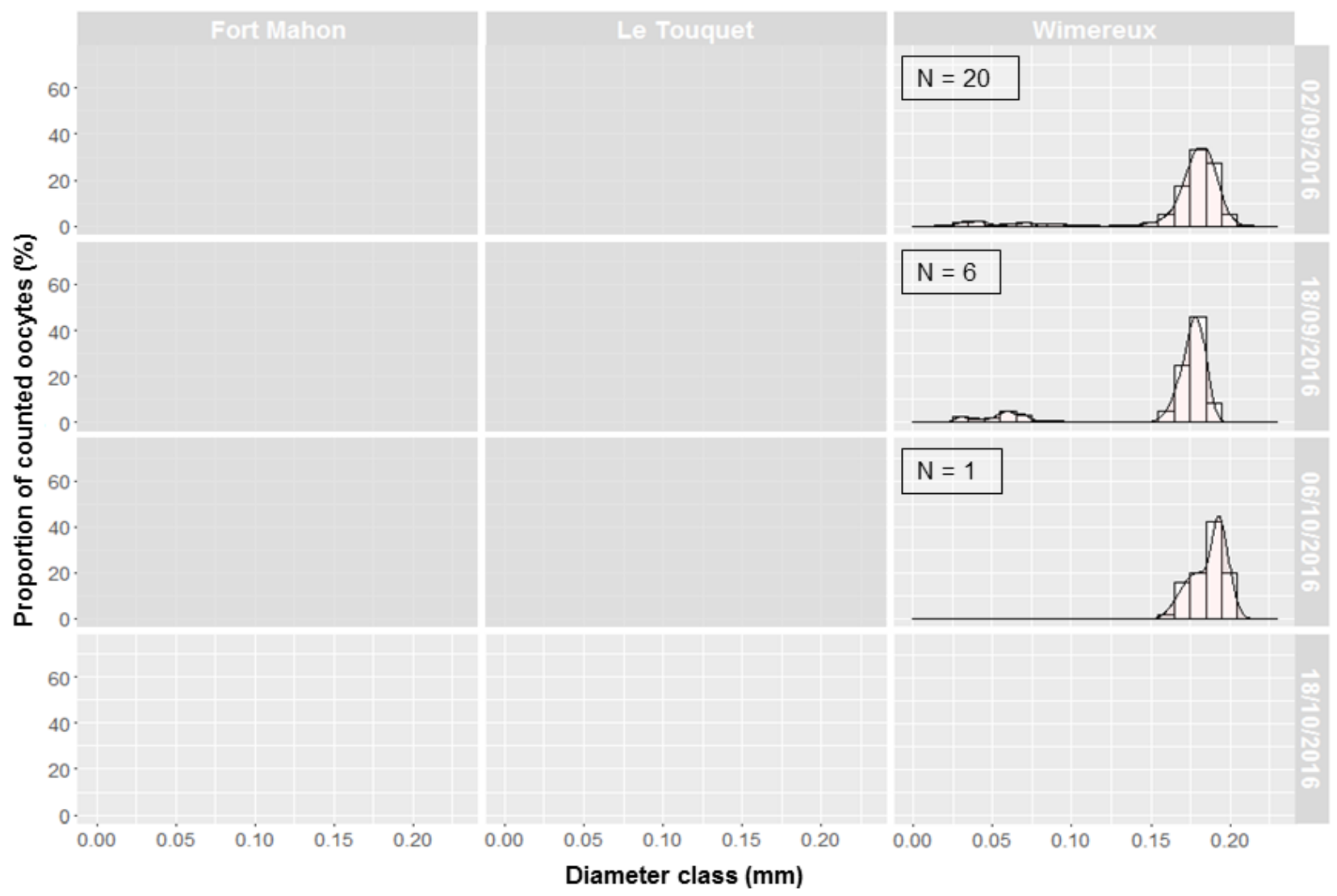


29 Figure G.3. Oocyte diameter distributions of the collected females ( $\mathrm{N}$ is the number of

30 females) of Arenicola defodiens at all sites in autumn and winter 2015/2016. When boxes

31 appear darker, the sites were not sampled at the corresponding date.

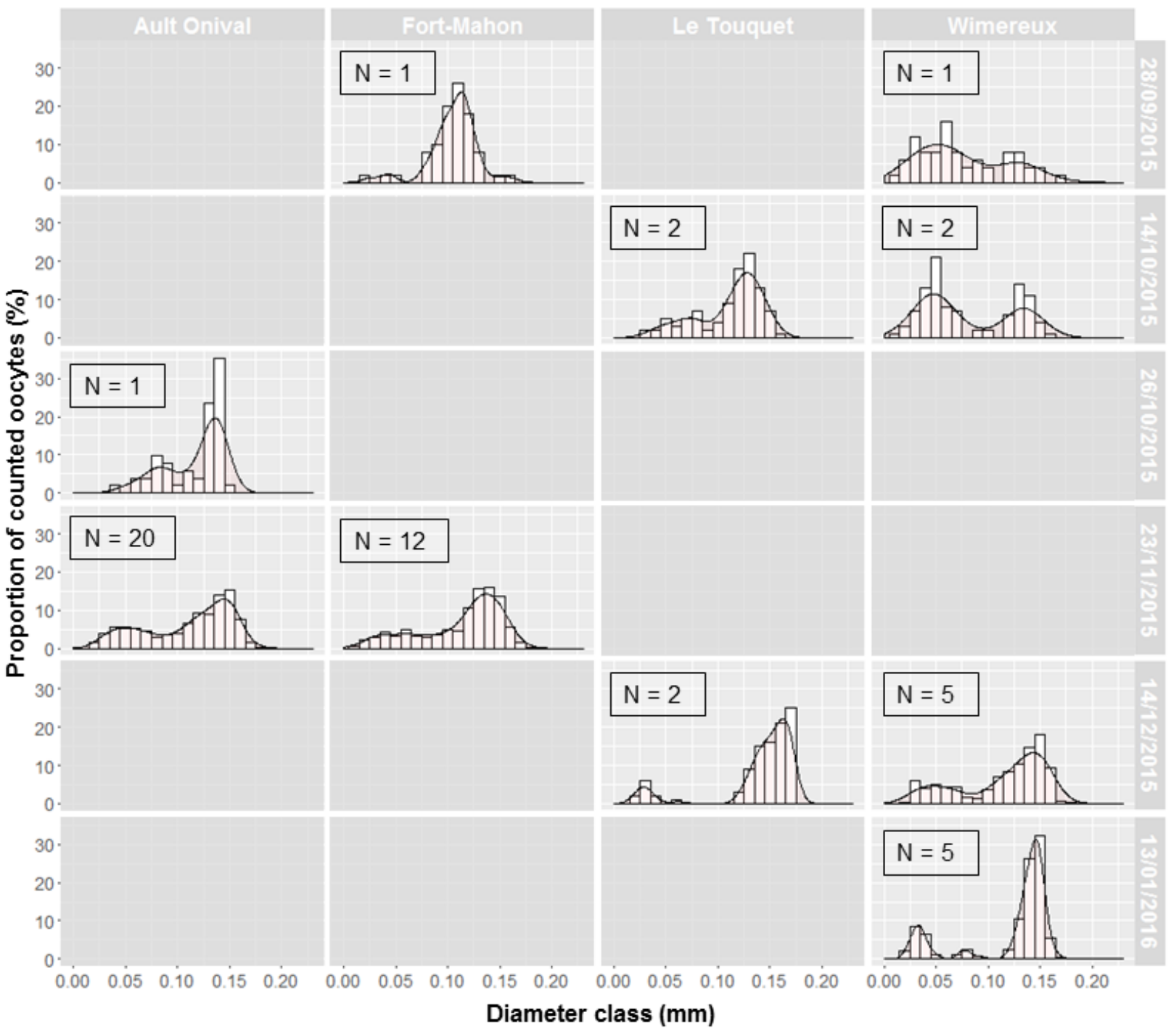


33 Figure G.4. Oocyte diameter distributions of the collected females $(\mathrm{N}$ is the number of

34 females) of Arenicola defodiens at Wimereux, Le Touquet and Fort Mahon in autumn and

35 winter 2016/2017. When boxes appear darker, the sites were not sampled at the

36 corresponding date.

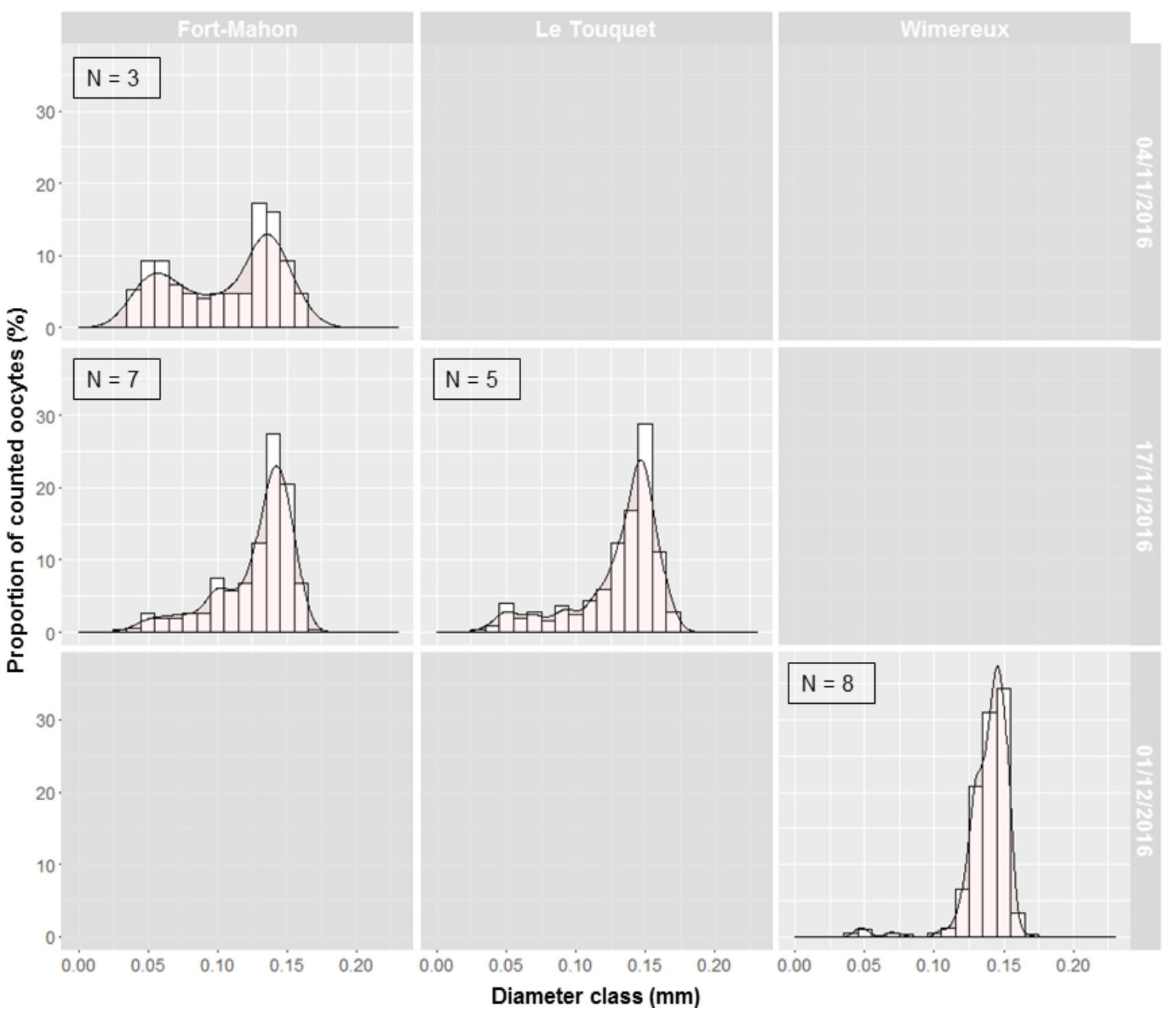


39 Figure H. Inferred spawning dates of Arenicola marina (red) and A. defodiens (blue) at all

40 sampled sites in 2015 (darker) and 2016 (lighter) and associated tide coefficients (in black)

41 and water temperatures (in green).

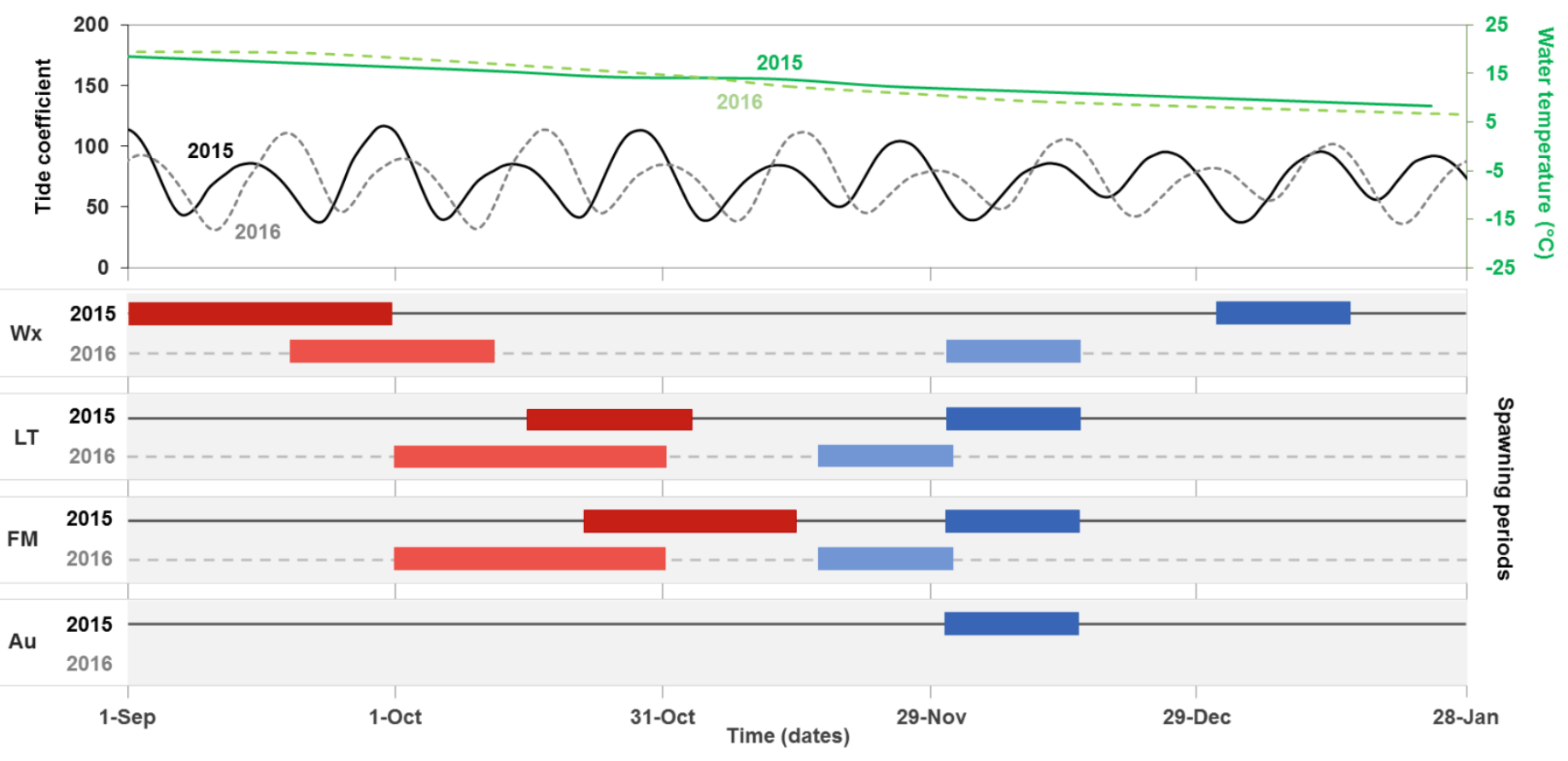


